Norambuena F, Estevez A, Mananos E, Bell J, Carazo I \& Duncan N (2013) Effects of graded levels of arachidonic acid on the reproductive physiology of Senegalese sole (Solea senegalensis): fatty acid composition, prostaglandins and steroid levels in the blood of broodstock bred in captivity, General and Comparative Endocrinology, 191, pp. 92-101.

This is the peer reviewed version of this article 


\section{EFFECTS OF GRADED LEVELS OF ARACHIDONIC ACID ON THE 2 REPRODUCTIVE PHYSIOLOGY OF SENEGALESE SOLE (SOLEA SENEGALENSIS): 3 FATTY ACID COMPOSITION, PROSTAGLANDINS AND STEROID LEVELS IN THE 4 BLOOD OF BROODSTOCK BRED IN CAPTIVITY}

5 Fernando Norambuena $^{1}$, Alicia Estévez ${ }^{1}$, Evaristo Mañanós ${ }^{2}, \mathrm{~J}_{\text {Gordon }}$ Bell $^{3}$, Ignacio Carazo ${ }^{1}$, 6 Neil Duncan $^{1}$

7 IRTA-Sant Carles de la Rápita, Ctra. Poble Nou Km 6, 43540-Sant Carles de la Ràpita, 8 Tarragona, Spain

$9 \quad{ }^{2}$ Institute of Aquaculture of Torre la Sal, Spanish Council for Scientific Research (CSIC), Torre la Sal s/n, 12595-Cabanes, Castellón, Spain

$11{ }^{3}$ Institute of Aquaculture, School of Natural Sciences, University of Stirling, Stirling FK9 4LA, 12 Scotland, UK

*Corresponding author: Fernando Norambuena, Phone: +34- 977 745427, Fax +34-977744138 email: norambuena52@ hotmail.com

\section{Abstract}

Previous studies on Senegalese sole (Solea senegalensis) indicated that cultured broodstock (first generation, G1) have lower tissue levels of arachidonic acid (20:4n-6, ARA) than wild counterparts. ARA is metabolized to form prostaglandins (PGs) that are involved in steroid production and follicle maturation in fish. In the present study the effects of different dietary levels of ARA on blood lipid and fatty acid composition, prostaglandin (PGF2 $\alpha$, PGF3 $\alpha$, PGE2 and PGE3) levels and plasmatic steroid levels (11-ketotestosterone, 11-KT, testosterone, $\mathrm{T}$ and estradiol, E2) in G1 Senegalese sole were studied. For this purpose, 12 groups of ten fish (1:1 male and female), were fed six diets (each diets was fed to two groups) with different dietary ARA levels over nine months (diets $\mathrm{A}=0.7, \mathrm{~B}=1.6, \mathrm{C}=2.3, \mathrm{D}=3.2, \mathrm{E}=5.0, \mathrm{~F}=6.0 \% \mathrm{ARA}$ ). ARA and CHOL levels in blood showed a significant increase in an ARA dose related manner $(P<0.05)$ whereas EPA and EPA/ARA ratio were reduced. In males, steroid $(11-\mathrm{KT}$ and $\mathrm{T})$ 
levels increased significantly with increasing dietary ARA in a dose dependent manner, whereas in females E2 did not show any change related to dietary ARA content. Plasma concentration of 3-series PGs (i.e., PGE3 and PGF3 $\alpha$ ) were reduced in parallel to increased ARA levels in blood $(P<0.05)$ and levels of PGs 3 -series were always higher than 2 -series PGs (PGE2 and PGF2 $\alpha)$. In conclusion there is an effect of dietary ARA on steroid production of Senegalese sole males, which might have important consequences in the reproduction of cultured fish.

Keywords:

Senegalese sole, fish blood, arachidonic acids, prostaglandins, steroids.

\section{Introduction}

The spawning performance of cultured Senegalese sole (Solea senegalensis) broodstock (G1 generation) was poor compared to wild counterparts. Cultured females released eggs, but no courtship between males and females was observed and the eggs collected were not fertilized [8]. Fatty acids and in particular polyunsaturated fatty acids (PUFAs) including arachidonic acid endocrine function $[1,14,25,26,34,37,47,49,53,54]$. The metabolites of ARA act as mediators or regulators in the cardiovascular, immune, nervous [51] and in particular the reproductive system $[1,51,53,54,65-67,69]$. Thus, ARA has been shown to stimulate ovarian and testicular steroid production in goldfish and trout, this being the steroid production blocked by indomethacin a well-known cyclooxygenase (COX-2) inhibitor suggesting that ARA exerts its effects by its conversion to prostaglandins [35, 36, 64-66, 68]. Evidence for a role of PG in mediating maturation or ovulation has been implicated from studies carried out with several different species of fish including goldfish (Carassius auratus) [59], brook trout (Salvelinus fontinalis ) [19], yellow perch (Perca flavescens) [18], European sea bass (Dicentrarchus labrax) [54] and Atlantic croaker (Micropogonias undulatus) [46]. In vitro studies in teleost fish examining the effects of ARA and its COX-2 metabolites on testosterone production have shown that PGE2 is synthesized within the gonads where it stimulates ovarian and testicular steroidogenesis and follicle maturation [35, 53, 54, 65, 66]. In addition, ARA and its metabolites have been shown to regulate the cholesterol (CHOL) transfer from outer to inner mitochondrial membrane where the P450 enzyme initiates steroid hormone synthesis, using CHOL as a 
57 precursor [24]. Studies in gold fish ovaries showed that the levels of steroids in the ovary 58 increased significantly prior to the increase in transcript COX-2 [32]. However, ARA has 59 different effects on steroid biosynthesis, on one hand ARA is involved in testosterone production 60 by elevating cyclic adenosine monophosphate (cAMP) levels in a dose dependent manner [35, 61 36]. On the other hand, at high doses, ARA might inhibit the biosynthesis of steroid hormones, in 62 spite of elevated cAMP, by affecting the availability of $\mathrm{CHOL}[35,36]$ and the steroidogenic 63 acute regulatory protein expression (StAR protein) that regulates CHOL transfer within the 64 mitochondria $[24,70]$.

Although ARA is the main precursor of PGs, these metabolites can also be produced from eicosapentaenoic acid (20:5 n-3, EPA), which is a substrate for biosynthesis of 3-series PGs [50, 61]. Metabolites, produced from EPA, had modest effects on basal testosterone production in the goldfish testis but blocked the ARA-derived steroid production and cAMP formation due to competition for the same enzyme [5, 35, 68]. The production of 2- or 3-series PGs is determined by the EPA/ARA ratio in cellular membranes that was dependent on the dietary intake of each fatty acid [3, 4, 6, 44, 62].

Recent studies on the fatty acid composition of Senegalese sole broodstock have shown that G1 fish, both males and females, had significantly lower accumulation of ARA in their tissues compared to wild counterparts [40-42, 44]. Low levels of CHOL were also found in the liver of G1 fish [42], which might have a consequence in reproduction considering its involvement in the production of fat-soluble vitamins and steroid hormones [2, 24]. On the other hand, 2-series PGs (F- and E-isomers) were produced in higher amounts in wild fish and PGs of the 3-series were higher in G1 fish [44]. Studies in ARA dietary self-selection by G1 Senegalese sole have also shown changes in ARA preferences along the year, with periods of high (winter and summer) and low (spring and autumn) ARA demand [40,43]. Senegalese sole is a seasonal spawner, with full gonadal development in early spring (April-May), and maximum levels of plasma steroids peaking at the beginning of the spawning season $[15,21,22]$. In wild fish peak levels of steroids were always higher than those reported in G1 fish [15-17]. Thus, there is a reproductive dysfunction of Senegalese sole with (1) G1 fish showing a complete absence of reproductive behaviour and synchronization of the spawning, (2) G1 fish having lower ARA and CHOL 
content in tissues, (3) lower production of 2-series PGs compared to wild fish and (4) lower levels of circulating testosterone.

Considering the above statements, a study of the effect of graded levels of dietary ARA on blood lipid and fatty acid composition, prostaglandin and steroid production of G1 Senegalese sole was conducted. For this, six groups of fish were fed six different diets with graded ARA levels for nine months. Total lipid content, fatty acid composition and steroid (11-KT, T and E2) production was analyzed monthly in the blood, and in May, during the spawning season, fish were also sampled to analyze PG levels (PGF2 $\alpha$, PGF3 $\alpha$, PGE2 and PGE3).

\section{Materials and methods}

Research involving animal experimentation conformed to the principles for the use and care of laboratory animals, in agreement with the Spanish and European regulations on animal welfare (FELASA).

\subsection{Fish}

One hundred and twenty, 4 year-old $(524 \pm 11 \mathrm{~g})$ fish reared in captivity were tagged with passive integrated transponders (PIT tags, AVID, UK) and sexed by using a heterologous vitellogenin ELISA for European seabass (Dicentranchus labrax) [33]. The fish were distributed among twelve experimental tanks (10 fish per tank, 5 males and 5 females) and fed six experimental diets (Table 1) with different ARA content: diet $\mathrm{A}=0.7, \mathrm{~B}=1.6, \mathrm{C}=2.3, \mathrm{D}=3.2$, $\mathrm{E}=5.0, \mathrm{~F}=6.0 \%$ of total fatty acids (TFA) (Table 2) over nine months. Biochemical analyses of the diets were performed every three months in duplicate. The fish were held in a recirculation system with a simulated natural photoperiod and temperature $\left(40^{\circ} 37^{\prime}\right.$ and $40^{\circ} 48^{\prime} \mathrm{N}$ and between $0^{\circ} 21^{\prime}$ and $0^{\circ} 40^{\prime}$ E., Tarragona, Spain), with minimal temperature in January February $\left(13^{\circ} \mathrm{C}\right)$ and maximal in June - September $\left(20^{\circ} \mathrm{C}\right)$. The fish were fed six days per week with a daily ration of $0.15-0.3 \%$ body weight. The fish received the diets over nine months, from September 2009 until June 2010. Specific growth rate SGR=100 $\left.\times\left[\left(\operatorname{lnwt}_{2}-\operatorname{lnwt}_{1}\right) \times\left(t_{2}-t_{1}\right)^{-1}\right]\right)$ was calculated where $\mathrm{wt}_{2}=$ final weight, $\mathrm{wt}_{1}=$ initial weight, and $\left(t_{2}-t_{1}\right)=$ days of experiment. 
In September 2009 and then in a monthly basis, from December 2009 until the end of the experiment in June 2010, a blood sample of $2.0 \mathrm{~mL}$ was collected using cold heparinized syringes. The fish were not fed the previous day and blood samples were collected from the caudal vein of the fish three hours after the light of the tank was switched on. The erythrocyte volume fraction was calculated and the samples centrifuged at $3000 \mathrm{x} \mathrm{g}$ for 15 minutes at $4^{\circ} \mathrm{C}$ to separate plasma and red cells in eppendorf tubes. A fraction $150 \mu \mathrm{L}$ was separated from the plasma for posterior steroid analysis (from December 2009 until June 2010) and a further $550 \mu \mathrm{L}$ used for prostaglandins analysis in May 2010. Fatty acid profile was determined from the erythrocyte fraction at the beginning of the experiment and in September and December 2009 and March and May 2010. All the samples were stored at $-80^{\circ} \mathrm{C}$, until analysis.

\subsection{Lipids and fatty acids}

Total lipids were extracted from red blood cell samples and diets [11]. Fatty acid methyl esters (FAME) prepared by acid-catalysed transmethylation [9] and FAME were extracted and purified [63]. FAME were separated and quantified by gas-liquid chromatography (Thermo Trace GC, Thermo Finningan, Milan, Italy) using a $30 \mathrm{~m}$ x $0.25 \mathrm{~mm}$ ID capillary column (BPX 70, SGE Europe Ltd., UK) with on-column injection and flame ionization detection using Helium as carrier gas $\left(1.2 \mathrm{~mL} \mathrm{~min}^{-1}\right.$ constant flow rate). Individual methyl esters were identified by comparison with known standards (Supelco Inc., Madrid) and a well characterized fish oil, and quantified by the response factor to the internal standard, 21:0. The results were presented as percentage $(\%)$ of the total fatty acids (TFA) as mean \pm standard error of the mean (SEM).

Lipid class composition in blood and diets was determined by high-performance thin layer chromatography (HPTLC) using 10×10 cm HPTLC plates (Macherey-Nagel gMBh \& Co, Düren, Germany). Approximately $10 \mu \mathrm{g}$ of total lipid were applied as $2 \mathrm{~mm}$ streaks, $1 \mathrm{~cm}$ from the bottom, and the plates developed in methyl acetate/ isopropanol/ chloroform/methanol/0.25\% aqueous $\mathrm{KCl}$ (25: 25: 25: 10: 9, by vol.) to two-thirds up the plate. After desiccation for $20 \mathrm{~min}$, the plate was fully developed with isohexane/diethyl ether/acetic acid (85:15:1, by vol.) and placed in a vacuum desiccator for $20 \mathrm{~min}$. The lipid classes were visualized by charring at 160 ${ }^{\circ} \mathrm{C}$ for $15 \mathrm{~min}$ after spraying with $3 \%(\mathrm{w} / \mathrm{v})$ aqueous cupric acetate containing 8\% (v/v) 
phosphoric acid and quantified by densitometry using a BIO-RAD GS-800 calibrated densitometer (BIO-RAD, Spain) and WINCATS software [23]. The identities of individual lipid classes were confirmed by comparison with authentic standards, however, only CHOL data was presented. The results of CHOL were presented as percentage (\%) of total lipids (TL) as mean \pm SEM.

\subsection{Eicosanoids extraction}

The samples of frozen acidified plasma were thawed and centrifuged at $12000 \mathrm{x} \mathrm{g}$ for $2 \mathrm{~min}$ to remove precipitates. The supernatants were extracted using octadecyl silyl (ODS, C18) Sep-Pak mini-columns (Millipore, Watford, UK) by the method of Powell [48] described in detail previously [5]. The Sep-Pak cartridges were then washed with $10 \mathrm{~mL}$ water and $5 \mathrm{~mL}$ methanol and the plasma samples loaded onto the cartridge with a flow rate of $2 \mathrm{~mL} \mathrm{~min}^{-1}$. The cartridge was washed with $5 \mathrm{~mL} \mathrm{15 \%}$ ethanol, to remove polar lipids, $10 \mathrm{~mL}$ distilled water, to restore the initial polarity of the cartridge and $5 \mathrm{~mL}$ hexane/chloroform $(65: 35 \mathrm{v} / \mathrm{v})$. Eicosanoids were then eluted with $10 \mathrm{~mL}$ ethyl acetate and solvent evaporated with $\mathrm{N}_{2}$. The final extract was redissolved in $100 \mu \mathrm{L}$ methanol prior to separation by HPLC.

\subsubsection{Separation by HPLC and quantitation of prostaglandins}

The homologues of PGs 2- and 3-series were separated by reverse phase HPLC using a column ODS2-SB5 and the methodology described previously [5]. An isocratic solvent system was employed containing $17 \mathrm{mM}$ phosphoric acid/acetonitrile (70/30, v/v at a flow rate of $1 \mathrm{~mL} \mathrm{~min}^{-}$ ${ }^{1}$ ). The elution times of the PGs standards (PGF2 $\alpha$, PGF3 $\alpha$, PGE2 and PGE3) were determined by UV detection at $205 \mathrm{~nm}$ using a Pye-Unicam LC-UV detector. A total of $100 \mathrm{uL}$ of the eicosanoid plasma extracts were injected into the column and $6 \mathrm{ml}$ fractions were collected using an LKB 2112 Redirac. Fractions corresponding to 2- and 3-series were extracted as follows: the pooled fractions were applied to a C18 Sep-Pak, which had been pre-washed with $5 \mathrm{ml}$ methanol and $10 \mathrm{ml}$ distilled water. The column was then washed with a further $10 \mathrm{ml}$ of distilled water and the PGs eluted in $5 \mathrm{ml}$ of ethyl acetate. Samples were dried under nitrogen and re-dissolved in immunoassay buffer. Quantification of PGs homologues was performed using enzyme immunoassay (EIA) kits for PGF and PGE prostaglandins according to the manufacturers 
171 protocol (Cayman®). The cross-reactivity of the PGF2 $\alpha$ and PGE2 antibody with PGF3 $\alpha$ and 172 PGE3 was $80 \%$ and $65 \%$ respectively.

173

174

175

176

177

178

179

180

181

182

183

184

185

186

187

188

189

190

191

192

193

194

195

196

197

\subsection{Steroids}

Analysis of 11-ketotestosterone (11-KT), testosterone (T) and estradiol (E2) were performed in the plasma of males (11-KT and T) and females (E2). Plasma samples were first extracted with alcohol. Ice-cold methanol was added to the plasma (6:1 v/v), shaken and centrifuged $(3000 \mathrm{~g}, 15$ $\min , 4{ }^{\circ} \mathrm{C}$ ). The pellet was re-extracted twice with $200 \mu \mathrm{L}$ methanol. Supernatants were pooled, dried and reconstituted in $0.1 \mathrm{M}$ potassium phosphate buffer $(\mathrm{pH} 7.4)$, then stored at $-20^{\circ} \mathrm{C}$ until analysis. Levels of 11-ketotestosterone, testosterone and estradiol were quantified by ELISA, using a protocol previously validated for Senegalese sole [22].

\subsection{Statistics analysis}

Statistical differences in lipid, fatty acids, lipid classes, prostaglandins, and steroids between different fish groups of males and females were analysed by one-way ANOVA followed by the post-hoc multiple comparison by Tukey's HSD with a significance level of $P<0.05$. In the case of steroids the group fed diet A was used as control. Pearson correlations among ARA, steroids, CHOL and PGs were made, using $P$ of 0.05 . The compliance of data with normality and homogeneity of variance was tested by the Kolmogorov-Smirnov and Bartlett (Chi-Sqr) methods and, when necessary, log-transformation was carried out. Fatty acid content was expressed as $\% \mathrm{TFA}$, and lipid class as $\% \mathrm{TL}$. The prostaglandins were expressed in $\mathrm{pg} \mathrm{ml}^{-1}$ of plasma and steroids as $\mathrm{ng} \mathrm{ml}^{-1}$ of plasma, both as mean of percentage \pm standard error of the mean (SEM). The statistical analysis was performed using the Statistica ${ }^{\circledR}$ package for windows (version 6.0; StatSoft Inc, Tulsa, USA).

\section{Results}

Groups A (control), B, C, D, E and F were fed diets with increasing levels of ARA (Table 2). Total lipid and CHOL content were the same in all the diets used (Table 3). After the nine month feeding period, females increased their weight from $533 \pm 13 \mathrm{~g}$ to $950 \pm 25 \mathrm{~g}$, with a specific growth rate (SGR) of $0.20 \% \mathrm{dia}^{-1}$ and males from $515 \pm 16 \mathrm{~g}$ to $755 \pm 24 \mathrm{~g}$, with an SGR of 
$0.13 \%$ day $^{-1}$. Feed conversion rate was $1.3 \pm 0.04$, and no significant differences were observed among the six groups, either in growth or feed conversion.

\subsection{Monthly changes in ARA content in blood}

Blood fatty acid composition was analyzed from the samples taken in September and December 2009 and in March and May 2010. ARA content was $3.6 \pm 0.3 \%$ in males and $3.4 \pm 0.2 \%$ TFA in females at the beginning of the feeding period (September 2009). During the experiment the content of ARA increased significantly $(P<0.05)$ in the blood of all the fish groups except in group A (control) and in the females from group B (Figs. 1 and 2). In December 2009, ARA in both males and females showed significant differences among all the groups $(P<0.05)$ and these differences were maintained until the end of the experiment (Fig. 1). Thus, male fish from group F showed $8.7 \pm 0.8 \%$ ARA in the blood, 3.1-fold higher than the control group A $(2.8 \pm 0.2 \%$ ARA) $(P<0.05)$ whereas the fish from groups $\mathrm{E}, \mathrm{D}$ and $\mathrm{C}$ had $7.3 \pm 0.4 \%, 6.7 \pm 0.8 \%$ and $5.5 \pm$ 0.6\% ARA, respectively all being significantly higher than the control $(P<0.05)$. Fish from group B also showed an increase in ARA levels but not significantly different from the control. In the case of females, in December 2009 the fish from groups F ( $8.6 \pm 0.4 \%$ ARA, 2.5-fold higher than the control), E (8.4 $\pm 0.8 \%$ ARA) and D $(7.4 \pm 0.7 \%$ ARA $)$ showed a significant $(P<0.05)$ increase in ARA levels compared to the control A. Fish from the groups $\mathrm{C}$ and $\mathrm{B}$ also exhibited an increase in levels of ARA in blood, but not significantly higher than control A. After this initial increase in ARA content found in December, ARA remained stable within each group throughout the following months with the values recorded in March very similar to those of December with a slight increment in the fish from groups $\mathrm{E}$ (males) and F (both females and males). In March 2010 the males of all the groups and the females of groups F, E, D and C showed ARA values significantly higher than the control $(P<0.05)$. In May 2010 significantly higher ARA levels were found in groups $\mathrm{F}, \mathrm{E}, \mathrm{D}$ and $\mathrm{C}$ in both sexes $(P<0.05)$ compared to group A (Fig. 1). Male fish fed diet F showed a slight ARA reduction compared to the levels found in March, while females from groups C, B and control showed a slight increment in ARA compared to March. 
228

229

230

231

232

233

234

235

236

237

238

239

240

241

242

243

244

245

246

247

248

249

250

251

252

253

254

255

All the fish showed a similar EPA/ARA ratio $(2.3 \pm 0.2)$ in September, at the beginning of the experiment (Fig. 2). In December the ratio was significantly reduced in both males and females from groups F, E, D and C and these were maintained until May. In the case of males, groups F $(0.8 \pm 0.1), \mathrm{E}(1.1 \pm 0.1), \mathrm{D}(1.2 \pm 0.2), \mathrm{C}(1.7 \pm 0.4)$ and $\mathrm{B}(2.1 \pm 0.2)$ showed a significantly $(P<0.05)$ lower ratio than the control A $(3.5 \pm 0.4)$, similar to observations in females from groups F $(1.1 \pm 0.1), \mathrm{E}(1.2 \pm 0.2), \mathrm{D}(1.4 \pm 0.1), \mathrm{C}(1.7 \pm 0.4)$ and $\mathrm{B}(2.1 \pm 0.2)$. In females, all except $\mathrm{B}$, had significantly lower ratios than group A $(3.5 \pm 0.1)$, that showed an increase in the ratio in both sexes (Fig. 2). In March fish from groups A and B exhibited an increase in the ratio whereas those from F, E, D, and C continued with decreasing values. In May all the groups, including $\mathrm{B}$ and in both sexes showed lower EPA/ARA ratio than the control $\mathrm{A}(P<0.05)$.

\subsection{Fatty acid composition of the blood at the end of the feeding period (May 2010)}

ARA levels in the blood measured at the end of the experiment (May 2010) were significantly higher $(P<0.05)$ in group F, E, D, C and B in males and the same was observed in females for group F, E, D and C compared to the initial values in September 2009 at the start of the experiment (3.6 \pm 0.3 in males and $3.4 \pm 0.2 \%$ TFA in females) (Tables 4 and 5). The ARA content in blood varied in a range from $3.5 \pm 0.2$ from group A (control, both sexes) to $10.3 \pm 0.3$ and $8.7 \pm 0.6 \%$ in females and males of group $F$ (Tables 4 and 5). ARA levels of fish from group A (both sexes) in May 2010 were similar and not significantly different to those found in September. In contrast, in May 2010, EPA levels in the blood of group A were $9.4 \pm 0.3 \%$ in males which was significantly higher $(P<0.05)$ than those recorded in September 2009 and from groups F, E, D, C and B in May 2010. In females the May 2010 group A level of EPA was $9.0 \pm$ $0.5 \%$, which was similar to the initial September level and final levels in groups B and C, whilst significantly higher $(P<0.05)$ than those recorded groups $\mathrm{F}, \mathrm{E}$ and $\mathrm{D}$ (Tables 4 and 5).

The fatty acid 22:4n-6 levels were significantly higher $(P<0.05)$ in the blood of the males and females from groups F, E, D and C compared to group A and the initial September level. Similarly the fatty acid 22:5n-6 was higher in the blood of fish from group F compared to the control A $(P<0.05)$, in both males and females due to elongation and desaturation of ARA to 22:4n-6 and 22:5n-6 respectively. Total lipid and total fatty acid content were similar and not 
significantly different in all the groups (from A to F), either compared to the beginning or among groups at the end of the feeding period and in both sexes.

\subsection{Cholesterol in blood}

At the end of the experiment in May 2010, CHOL levels exhibited a positive correlation in males and females $\left(\mathrm{r}^{2}=0.8, P<0.05\right)$ with dietary ARA levels (not shown). In male fish from groups $\mathrm{F}$ and $\mathrm{E}, \mathrm{CHOL}$ levels in the blood were $32 \pm 1.6$ and $30 \pm 1.9 \% \mathrm{TL}$, which was significantly higher $(P<0.05)$ than the levels found in the males from groups $\mathrm{C}, \mathrm{B}$ and $\mathrm{A}$ that exhibited levels of $23 \pm 1.1 \%, 24 \pm 0.8 \%$ and $22 \pm 0.9 \%$ TL respectively $(P<0.05)$ (Fig. 3). Males from group D had an intermediate value, $26 \pm 0.6 \%$, which was not different from the other groups. In the case of female fish from groups $\mathrm{F}(35 \pm 1.3), \mathrm{E}(33 \pm 1.5)$ and $\mathrm{D}(30 \pm 1.8)$ CHOL were significantly higher compared to the control A $(26 \pm 0.7)(P<0.05)$ (Fig. 3). The CHOL in diets was $12 \pm$ $0.8 \%$, and no significant differences among diets were found (Table 3 ).

\subsection{Prostaglandins in blood}

Prostaglandins were measured at the end of the experiment, in May 2010. Plasma concentration of PGs 3-series was always higher than PGs 2-series PGs in all the fish groups studied (Figs. 4 and 5). Thus, PGF3 $\alpha$ was significantly $(P<0.05)$ higher than PGF2 $\alpha$ in both females and males of the control and females in group B. Similarly, higher PGE3 levels were found in both sexes compared to PGE2, although in this case the differences were not significant. PGs 3-series concentration showed a negative correlation with ARA in blood of males and females $\left(r^{2}=0.45\right.$, $P<0.05$, Fig. 5) and consequently no statistical differences were found between PGs 2- and 3series in groups $\mathrm{C}, \mathrm{D}, \mathrm{E}$ and $\mathrm{F}$ with the levels in groups, $\mathrm{D}, \mathrm{E}$ and $\mathrm{F}$ being similar in concentration and between sexes. In the case of PGs 2-series, the levels found in the plasma of males and females did not change with the diet, although PGs F2-isomers were always found in higher concentration than PG E2-isomers in both sexes.

\subsection{Plasma steroids levels}

The sex hormone, 11-ketotestosterone (11-KT) was the most concentrated steroid in males with plasma levels varying between 2.2 and $16.4 \mathrm{ng} \mathrm{ml}^{-1}$, compared to testosterone (T) with 0.8 - 2.2 $\mathrm{ng} \mathrm{ml}^{-1}$ (Fig. 6). The levels of both esteroid hormones were significantly $(P<0.05)$ affected by the 
diet in the month of April in groups $\mathrm{E}$ and $\mathrm{F}$ for 11-KT (Figs. 6d and 6e) and in group D for T (Fig. 6c). Although the levels were not significantly different from the control group, during the months of February, March, April and May the fish fed diets D, E and F exhibited higher plasmatic levels of steroids. Plasma estradiol (E2) levels in females were similar in all the groups, although in group B a slight but not significant increment was observed (Fig. 7a).

Circulating 11-KT, T, and E2, followed a seasonal trend (Figs. 6 and 7). In males, an increase in the titre of steroid levels was detected between January and February with plasma concentrations of both androgens increasing progressively to a significantly $(P<0.05)$ higher peak found in April. Thereafter steroid levels gradually declined until reaching minimal initial values in June 2010. In females an increase in E2 levels was detected between January and February with plasma concentrations increasing progressively afterwards to reach a peak in March, one month earlier than in males, in all the groups except for the control which peaked in April. Then, plasma levels gradually declined until reaching the initial values in June 2010.

\section{Discussion}

This study was conducted to analyse the effects of six dietary ARA levels on the reproductive physiology of G1 Senegalese sole. Thus, the analysis of blood and plasma lipid and fatty acid composition, CHOL levels, prostaglandins and steroid production was carried out during the experiment. ARA levels increased in a dose dependent manner during the first period (September 2009 to December 2010) remaining stable throughout the rest of the experiment, in both sexes, to reach levels of around $8.5 \%$ TFA (groups E and F). In contrast to the ARA increase, EPA levels decreased and, consequently produced a decrease in the EPA/ARA ratio. Thus, dietary fatty acid composition had a direct effect on blood composition. Increasing ARA levels in blood had as a consequence an increase in the levels of 22:4n-6 and 22:5n-6 in males, a consequence of the elongation of ARA to 22:4n-6 and desaturation of this fatty acid to 22:5n-6 [31]. Long chain PUFAs (n-3 and n-6) have been detected in the spermatozoa of mammals $[7,13,29,30,60]$ and in the gonads of male marine fish (i.e., wild Senegalese sole) being these fatty acids, 22:4n-6 and 22:5n-6 closely related to the sperm membrane fluidity needed to participate in the membrane fusion events associated with fertilization [30]. The diets used in the experiment were formulated using high quality northern fish oil (G. Rosenlund, pers. Comm. 2011, Skretting, Norway) with similar levels of EPA (approx., 15\% TFA) and DHA (approx., 13\% TFA) (see Table 2) with the 
variations in ARA as a consequence of the addition of a special ARA-rich oil. Thus, EPA content in the blood of the fish was very similar for all the groups and the variations in the ratio EPA/ARA were mostly a consequence of the graded ARA levels.

Both ARA and EPA are precursors of PGs, 2- and 3-series respectively [52, 61]. In the fish of the present experiment, PG 3-series were always higher than PG 2-series in spite of the increase in dietary ARA content. PGs F-isomer PGF2 $\alpha$, is responsible for the synchronization of courtship between male and female fish during spawning [20, 38, 55-58] whereas PGE2 is important for the follicle maturation and steroid production in ovaries and testis [10, 12, 27, 5557, 65, 66]. Thus, the low concentrations of PGs 2-series in G1 Senegalese sole found in this study, compared to those of PGs 3-series, might have a detrimental effect in fish reproduction. In previous studies the production of 2- and 3-series PGs was proportional to EPA/ARA ratio found in fish tissues, with the ARA dietary content having a direct effect on the production of 2-series PG $[4,5,40,44]$. In the present experiment, although PGs 3-series were always higher than 2series in both F- and E- isomers, both metabolites PGE3 and PGF3 $\alpha$ were reduced concomitant with the increase in ARA content in the blood. The high values of PGs 3-series might be explained by the high dietary EPA content and the high EPA/ARA ratio found in the diet, although the ratio was progressively reduced from diet A (24) to diet F (2.4). Consequently, an increase in dietary ARA produced a significant reduction of 3-series PGs, although the effects on fish reproduction (i.e., ovulation, spermiation or courtship behaviour) were not established. Further studies are required to clarify the effects of EPA content in the diet and COX pathway, since the optimal dietary ARA content will be strongly dependent on the EPA content.

Steroid production (11-KT and $\mathrm{T}$ ) in males was higher in fish fed increasing ARA levels especially in April at the peak of maturation, whereas E2 in females did not show any change. ARA and CHOL levels in blood also showed a significant increase in an ARA-dose dependent manner. In vitro studies with goldfish and trout have shown that an ARA-stimulated testosterone production via the COX pathway and the effect of the ARA was mediated through its conversion to PGs $[39,65,66,68]$. According to these studies, EPA exerted an opposite effect inhibiting testosterone production via the inhibition of cAMP production, with ARA-induced maturation depressed. Thus, an increase in the production of EPA-derived PGE3 had no effect on fish maturation $[53,54]$. Any change in dietary EPA/ARA ratio or in the levels of these two fatty 
acids in fish tissues may influence the production of PGs and steroids. The in vivo effects of increased dietary ARA in the present experiment are consistent with previous in vitro studies showing a significant positive correlation $\left(\mathrm{r}^{2}=0.7, P<0.05\right)$ between plasma steroid levels and dietary ARA. Thus, 11-KT and $\mathrm{T}$ in males showed a clear dietary response with blood ARA levels increasing and EPA/ARA ratio reduced, and with steroid levels increasing progressively to peak in April in all the groups. However, the steroid levels found in this study were lower than those reported in wild males of Senegalese sole (i.e., 11-KT peak of $\approx 33 \mathrm{ng} \mathrm{mL}^{-1}$ ) [15]. In females plasmatic levels of Estradiol (E2) did not show any increase derived from increasing ARA dietary content, only group B showed a higher but not significantly different peak of E2 similar to the levels found in wild and cultured females (i.e., aprox. 6-7 $\mathrm{ng} \mathrm{mL}^{-1}$ ) [21]. The peak in E2 levels was in March, one month earlier than in males, in all the groups except the control. Similar results have been found in other studies with marine fish in response to graded levels of dietary ARA, thus plasma vitellogenin concentration peaked one month earlier in cod fed increasing levels of ARA [45] and showed a two week delay in the spawning season in the case of halibut [1]. However, more studies are required to clarify the effects of dietary ARA on the steroid production in females. Changes in dietary CHOL could be affecting the steroid production in broodstock fish [2]. In the present study, blood ARA and CHOL levels increased in parallel $\left(\mathrm{r}^{2}=0.8, P<0.05\right)$ to ARA in the diet, in spite of CHOL levels being the same in all the diets used (i.e., $12 \%$ TL, see Table 2). Thus, dietary ARA might have increased the mobilization of CHOL in the blood by means of cAMP formation [36]. Wang and Stocco [70] showed the interaction between ARA metabolism and CHOL during steroidogenesis in Leydig cells of rat, indicating that mobilization of $\mathrm{CHOL}$ regulated by StAR protein in turn affected ARA-mediated pathways and metabolites produced by lipoxygenase, epoxygenase and cyclooxygenase activity. Mercury and Kraak [35] demonstrated that EPA blocks cAMP formation and consequently StAR protein and the transport of $\mathrm{CHOL}$ in steroidogenic tissues. The results of the present experiment showed that EPA in blood was reduced in a dietary ARA dose-related manner $\left(r^{2}=0.6, P<0.05\right)$, therefore availability of ARA in blood (tissues) might be inducing StAR regulation and CHOL circulation, however StAR protein, lipooxygenase, epoxygenase and cyclooxygenase gene expression were not studied in the present experiment. Another explanation of $\mathrm{CHOL}$ incorporation in blood, is the biosynthesis by the fish. Leaver et al. [28] showed that Atlantic salmon increased CHOL biosynthesis after dietary substitution of fish oil with vegetable oil [28], 
however, in Senegalese sole there is no information regarding to the capacity of the fish for CHOL synthesis.

\section{Conclusion}

There was a significant effect of dietary ARA levels on steroid production in G1 Senegalese sole males, which might have important consequences in the reproduction of cultured fish although no effect was observed in females. Changes in dietary ARA content modified the fatty acid profile of fish blood, with a concomitant increase in ARA and a reduction of EPA and EPA/ARA ratio. Increased ARA levels in blood resulted in a reduction in the production of 3-series prostaglandins an increase of CHOL mobilization in the blood.

\section{Acknowledgments}

The authors gratefully thank to G. Rosenlund from Skretting ARC (Norway) for formulating and providing the diets used in the study. Thanks to N. Gras, G. Macia and J.R. Dick, F. Strachan, M.J. Bayarri and V. Piquer for technical support and Karl Andree for reviewing the MS. This research was funded by Ministerio de Agricultura, Pesca, Alimentación y Medio Ambiente JACUMAR Project Lenguado coordinated nationally by Pedro Cañavate and in IRTA by N.D. and (INIA)-FEDER project RTA2005-00113-00-00 coordinated by N.D. F.N. thanks Agència de Gestió d'Ajuts Universitaris i de Recerca (AGAUR) for the PhD grant that he was awarded.

\section{References}

[1] E. Alorend, The effect of dietary arachidonic acid concentration on Atlantic Halibut (Hippoglossus hippoglossus) broodstock performance, assessment of egg, milt and larval quality., PhD Thesis, Institute of Aquaculture University of Stirling, UK, 2004, p. 176.

[2] S.F. Baron, P.B. Hylemon, Biotransformation of bile acids, cholesterol, and steroids hormones. In: R.L.M.a.B.A. White (Ed.), Gastrointestrinal microbiology, Vol. 1, Chapman and Hall, London, England, 1997, p. 663.

[3] J.G. Bell, D.R. Tocher, F. MacDonald, J. Sargent, Effects of diets rich in linoleic $(18: 2 n-6)$ and $\alpha-$ linolenic $(18: 3 n-3)$ acids on the growth, lipid class and fatty acid compositions and eicosanoid production in juvenile turbot (Scophthalmus maximus), Fish. Physiol. Biochem. 13 (1994) 105118.

[4] J.G. Bell, D.R. Tocher, F.M. MacDonald, J.R. Sargent, Diets rich in eicosapentaenoic acid and [gamma]-linolenic acid affect phospholipid fatty acid composition and production of prostaglandins E1, E2 and E3 in turbot (Scophthalmus maximus), a species deficient in [Delta]5 fatty acid desaturase, Prostag. Leukotr. Ess. 53 (1995) 279-286.

[5] J.G. Bell, D.R. Tocher, J.R. Sargent, Effect of supplementacion with 20:3(n-6), $20: 4(n-6)$ and 20 : $5(n-3)$ on the production of prostaglnadins $E$ and $F$ of the 1-, 2- and 3-series in turbot 
(Scophthalmus maximus) brain astroglial cells in primary culture Biochem. Bioph. Res. Co. 1211 (1994) 335-342.

[6] M.V. Bell, J.R. Dick, M. Thrush, J.C. Navarro, Decrease 20:4n-6/20:5n-3 ratio in sperm from cultured sea bass, Dicentrarchus labrax, broodstock compared with wild fish Aquaculture 144 (1996) 189-199.

[7] R.B. Bridges, J.G. Coniglio, The Biosynthesis of $D^{9,12,15,18}$ Tetracosatetraenoic and of $D^{6,9,12,15,18}$ Tetracosapentaenoic acids by rat testes, BBA-Lipid Lipid Met. 245 (1970) 45-49.

[8] I. Carazo, I. Martin, P. Hubbard, O. Cherenguini, E. Mañanos, A. Canario, N. Duncan, Reproductive behaviour, the absence of reproductive behaviour in cultured (G1 generation) and chemical communication in the Senegalese sole (Solea senegalensis) Proceding of 9th ISRPF, Vol. 4, Indian J. Sci. Technol., Cochin, India., 9-14 August, 2011, p. 96.

[9] W.W. Christie, Lipid Analysis. Pergamon, Oxford, UK, 1982, p. 207

[10] L.L. Espey, J.S. Richards, Ovulation In: J.D. Neill (Ed.), The Physiology of Reproduction, vol. 1, 3rd ed. , Academic Press, Amsterdam, 2006, pp. 425-474

[11] J.M. Folch, M. Lees, G.H. Sloane Stanley, A simple method for the isolation and purification of total lipids from animal tissues, J. Biol. Chem. 226 (1957) 497-509.

[12] C. Fujimori, K. Ogiwara, A. Hagiwara, S. Rajapakse, A. Kimura, T. Takahashi, Expression of cyclooxygenase- 2 and prostaglandin receptor EP4b mRNA in the ovary of the medaka fish, Oryzias latipes: Possible involvement in ovulation, Mol. Cell. Endocrinol. 332 (2010) 67-77.

[13] N.E. Furland, E.N. Maldonado, P.A. Aresti, M.I. Aveldaño, Changes in lipids containing long- and very long-chain polyunsaturated fatty acids in cryptorchid rat testes, Biol. Reprod. 77 (2007) 181-188.

[14] H. Furuita, K. Hori, Suzuki, T. Sugita, T. Yamamoto, Effect of $n-3$ and $n-6$ fatty acids in broodstock diet on reproduction and fatty acid composition of broodstock and eggs in the Japanese eel (Anguilla japonica), Aquaculture 267 (2007) 55-61.

[15] A. García-López, V. Anguis, E. Couto, A.V.M. Canario, J.P. Cañavate, C. Sarasquete, G. MartínezRodríguez, Non-invasive assessment of reproductive status and cycle of sex steroid levels in a captive wild broodstock of Senegalese sole Solea senegalensis (Kaup), Aquaculture 254 (2006) 583-593.

[16] Á. García-López, E. Couto, A.V.M. Canario, C. Sarasquete, G. Martínez-Rodríguez, Ovarian development and plasma sex steroid levels in cultured female Senegalese sole Solea senegalensis, Comp. Biochem. Phys. A 146 (2007) 342-354.

[17] A. García-López, V. Fernández-Pasquier, E. Couto, A.V.M. Canario, C. Sarasquete, G. MartínezRodríguez, Testicular development and plasma sex steroid levels in cultured male Senegalese sole Solea senegalensis Kaup, Gen. Comp. Endocr. 147 (2006) 343-351.

[18] F. Goetz, P. Duman, A. Berndtson, E. Janowsky, The role of prostaglandins in the control of ovulation in yellow perch (Perca flavescens), Fish Physiol. Biochem. 7 (1989) 163-168.

[19] F.W. Goetz, F. Cetta, Ovarian and plasma PGE and PGF levels in naturally ovulating brook trout (Salvelinus fontinalis) and the effects of indomethacin on prostaglandin levels, Prostaglandins 26 (1983) 387-395.

[20] A.V. Golubev, Role of chemical stimuli in group and spawn-ing behavior of zebrafish, Brachidanio rerio, J. Ichthyol. 6 (1984) 1020-1027.

[21] J.M. Guzmán, B. Norberg, J. Ramos, C.C. Mylonas, E.L. Mañanós, Vitellogenin, steroid plasma levels and spawning performance of cultured female Senegalese sole (Solea senegalensis), Gen. Comp. Endocr. 156 (2008) 285-297.

[22] J.M. Guzmán, J. Ramos, C.C. Mylonas, E.L. Mañanós, Spawning performance and plasma levels of GnRHa and sex steroids in cultured female Senegalese sole (Solea senegalensis) treated with different GnRHa-delivery systems, Aquaculture 291 (2009) 200-209. 
[23] R.J. Henderson, D.R. Tocher, Thin-layer chromatography. In: R.J.H.S. Hamilton (Ed.), Lipid Analysis. A Practical Approach, IRL Press, Oxford, 1992, pp. 65-111.

[24] J. Hu, Z. Zhang, W.-J. Shen, S. Azhar, Cellular cholesterol delivery, intracellular processing and utilization for biosynthesis of steroid hormones, Nutr. Metab. 7 (2010) 47.

[25] M.D. Huynh, D.D. Kitts, C. Hu, A.W. Trites, Comparison of fatty acid profiles of spawning and non-spawning Pacific herring, Clupea harengus pallasi, Comp. Biochem. Physiol. B 146 (2007) 504-511.

[26] M.S. Izquierdo, H. Fernández-Palacios, A.G.T. Tacon, Effect of broodstock nutrition on reproductive performance of fish, Aquaculture 197 (2001) 25-42.

[27] M. Kobayashi, P.W. Sorensen, N.E. Stacey, Hormonal and pheromonal control of spawning behavior in the goldfish, Fish. Physiol. Biochem. 26 (2002) 71-84.

[28] M. Leaver, L. Villeneuve, A. Obach, L. Jensen, J. Bron, D. Tocher, J. Taggart, Functional genomics reveals increases in cholesterol biosynthetic genes and highly unsaturated fatty acid biosynthesis after dietary substitution of fish oil with vegetable oils in Atlantic salmon (Salmo salar), BMC Genomics 9 (2008) 299.

[29] A. Lenzi, L. Gandini, F. Lombardo, M. Picardo, V. Maresca, E. Panfili, F. Tramer, C. Boitani, F. Dondero, Polyunsaturated fatty acids of germ cell membranes, glutathione and blutathionedependent enzyme-PHGPx: from basic to clinic, Contraception 65 (2002) 301-304.

[30] A. Lenzi, M. Picardo, L. Gandini, F. Dondero, Lipids of the sperm plasma membrane: from polyunsaturated fatty acids considered as markers of sperm function to possible scavenger therapy, Hum. Reprod. Update 2 (1996) 246-256.

[31] F. Linares, R.J. Henderson, Incorporation of 14C-labelled polyunsaturated fatty acids by juvenile turbot, Scophthalmus maximus (L.) in vivo, J. Fish. Biol. 38 (1991) 335-347.

[32] A.L. Lister, G.J. Van Der Kraak, Regulation of prostaglandin synthesis in ovaries of sexuallymature zebrafish (Danio rerio), Mol. Reprod. Dev. 76 (2009) 1064-1075.

[33] E. Mañanós, J. Núñez, S. Zanuy, M. Carrillo, F. Le Menn, Sea bass (Dicentrarchus labrax L.) vitellogenin. II-Validation of an enzyme-linked immunosorbent assay (ELISA), Comp. Biochem. Physiol. B 107 (1994) 217-223.

[34] C. Mazorra, M. Bruce, J.G. Bell, A. Davie, E. Alorend, N. Jordan, J.F. Rees, N. Papanikos, M. Porter, N. Bromage, Dietary lipid enhancement of broodstock reproductive performance and egg and larval quality in Atlantic halibut (Hippoglossus hippoglossus), Aquaculture 227 (2003) 21-33.

[35] F. Mercure, G. Van der Kraak, Inhibition of gonadotropin-stimulated ovarian steroid production by polyunsaturated fatty acids in teleost fish, Lipids 30 (1995) 547-554.

[36] F. Mercure, G. Van der Kraak, Mechanisms of Action of Free Arachidonic Acid on Ovarian Steroid Production in the Goldfish, Gen. Comp. Endocr. 102 (1996) 130-140.

[37] O. Meunpol, P. Meejing, S. Piyatiratitivorakul, Maturation diet based on fatty acid content for male Penaeus monodon (Fabricius) broodstock, Aquac. Res. 36 (2005) 1216-1225.

[38] A. Moore, Electrophysiological and endocrinological evidence that F-series prostaglandins function as priming pheromones in mature male Atlantic salmon (Salmo salar) parr, J. Exp. Biol. 199 (1996) 2307-2316.

[39] T. Mustafa, K.C. Srivastava, Prostaglandins (eicosanoids) and their role in ectothermic organisms, Adv. Comp. Environ. Physol. 5 (1989) 157-207.

[40] F. Norambuena, Senegalese sole (Solea senegalensis) broodstock nutrition: arachidonic acid (20:4n-6, ARA) and reproductive physiology. PhD Thesis, Institute of Animal Biology, Vegetal and Ecology, Autonomous University of Barcelona, Spain, 2012, p. 187.

[41] F. Norambuena, A. Estevez, M. Andrés, I. Carazo, N. Duncan, Preliminary comparison of nutritional status of wild and cultured broodstock of Senegal sole (Solea senegalensis). XIII 
International Symposium on Fish Nutrition and Feeding Florianópolis, Brasil, 1-5 June, 2008, pp. 215-216

[42] F. Norambuena, A. Estevez, G. Bell, I. Carazo, N. Duncan, Proximate and fatty acid composition in muscle, liver and gonads of wild versus cultured broodstock of Senegalese sole (Solea senegalensis), Aquaculture 356-357 (2012) 176-185.

[43] F. Norambuena, A. Estevez, J. Sánchez-Vázquez, N. Duncan, Dietary self selection of arachidonic fatty acid $(20: 4 n-6)$ by senegalese sole (Solea senegalensis) broodstock 5th Workshop on the Cultivation of Soles CCMAR, University of the Algarve, Faro, Portugal. 5-7 April, 2011, p. 12

[44] F. Norambuena, S. Mackenzie, J.G. Bell, A. Callol, A. Estevéz, N. Duncan, Prostaglandin (F and E, 2-and 3-series) production and cyclooxygenase (COX-2) gene expression of wild and cultured broodtsock of Senegalese sole (Solea senegalensis), Gen. Comp. Endocr. 177 (2012) 256-262.

[45] B. Norberg, K. Hamre, P. Araujo, T. van der Meeren, G. Rosenlund, Effect of graded levels of arachidonic acid on reproductive physiology, spawning performance, and egg quality of atlantic cod 5th Fish \& shellfish larviculture symposium, European Aquacculture Society Oostende, Belgium, 7-11 September, 2009.

[46] R. Patiño, G. Yoshizaki, D. Bolamba, P. Thomas, Role of arachidonic acid and protein kinase C during maturation-inducing hormone-dependent meiotic resumption and ovulation in ovarian follicles of Atlantic Croaker, Biol. Reprod. 68 (2003) 516-523.

[47] J. Pickova, E. Brannas, T. Andersson, Importance of fatty acids in broodstock diets with emphasis on Arctic char (Salvelinus alpinus) eggs, Aquacult. Int. 15 (2007) 305-311.

[48] W.S. Powell, Rapid extraction of arachidonic acid metabolites from biological samples using octadecylsilyl silica, Methods Enzymol. 86 (1982) 467-477.

[49] C. Silversand, B. Norberg, C. Haux, Fatty-acid composition of ovulated eggs from wild and cultured turbot (Scophthalmus maximus) in relation to yolk and oil globule lipids, Mar. Biol. 125 (1996) 269-278.

[50] W.L. Smith, The eicosanoids and their biochemical mechanism of action Biochem J. 259 (1989) 315-324.

[51] W.L. Smith, R. Langenbach, Why there are two cyclooxygenase isozymes, J. Clin. Invest. 107 (2001) 1491-1495.

[52] W.L. Smith, R.C. Murphy, J.E.V. Dennis E. Vance, The eicosanoids: cyclooxygenase, lipoxygenase, and epoxygenase pathways, New. Compr. Biochem. 36 (2002) 341-371.

[53] L. Sorbera, S. Zanuy, M. Carrillo, A Role for polyunsaturated fatty acids and rostaglandins in oocyte maturation in the Sea bass (Dicentrarchus labrax), Ann. NY Acad. Sci. 839 (1998) 535-537.

[54] L.A. Sorbera, J.F. Asturiano, M. Carrillo, S. Zanuy, Effects of polyunsaturated fatty acids and prostaglandins on oocyte maturation in a marine teleost, the European Sea bass (Dicentrarchus labrax), Biol. Reprod. 64 (2001) 382-389.

[55] P.W. Sorensen, A.R. Brash, F.W. Goetz, R.G. Kellner, L. Bowdin, L.A. Verieze, Origins and funtions of $F$ prostaglandins as hormones and pheromones in the goldfish. Reproductive Physiology of Fish, Proceeding of 5th International Symposium, Austin, 1995, pp. 252-254

[56] P.W. Sorensen, N.E. Stacey, Brief review of fish pheromones and discussion of their possible uses in the control of non-indigenous teleost fishes, New Zeal. J. Mar. Fresh 38 (2004) 399-417.

[57] N.E. Stacey, A. Chojnacki, A. Narayanan, T. Cole, C. Murphy, Hormonally derived sex pheromones in fish: exogenous cues and signals from gonad to brain, Can. J. Physiol. Pharm. 81 (2003) 329-341.

[58] N.E. Stacey, F.W. Goetz, Role of prostaglandins in fish reproduction Can. J. Fish. Aquat. Sci. 39 (1982) 92-98

[59] N.E. Stacey, S. Pandey, Effects of indomethacin and prostaglandins on ovulation of goldfish, Prostaglandins 9 (1975) 597-607. 
[60] P.S. Tam, R. Sawada, Y. Cui, A. Matsumoto, Y. Fujiwara, The metabolism and distribution of docosapentaenoic acid ( $\mathrm{n}-6)$ in the liver and testis of growing rats, Biosci. Biotechnol. Biochem. 72 (2008) 2548-2554.

[61] D.R. Tocher, Metabolism and funtions of lipids and fatty acids in teleost fish, Rev. Fish. Sci. 11 (2003) 107-184.

[62] D.R. Tocher, E.Å. Bendiksen, P.J. Campbell, J.G. Bell, The role of phospholipids in nutrition and metabolism of teleost fish, Aquaculture 280 (2008) 21-34.

[63] D.R. Tocher, D.G. Harvie, Fatty acid compositions of the major phosphoglycerides from fish neural tissues; $(n-3)$ and $(n-6)$ polyunsaturated fatty acids in rainbow trout (Salmo gairdneri) and cod (Gadus morhua) brains and retinas, Fish. Physiol. Biochem. 5 (1988) 229-239.

[64] G. Van der Kraak, S. Biddiscombe, Polyunsaturated fatty acids modulate the properties of the sex steroid binding protein in goldfish, Fish. Physiol. Biochem. 20 (1999) 115-123.

[65] G. Van der Kraak, J.P. Chang, Arachidonic acid stimulates steroidogenesis in goldfish preovulatory ovarian follicles, Gen. Comp. Endocr. 77 (1990) 221-228.

[66] M.G. Wade, G. Van der Kraak, Arachidonic acid and prostaglandin E2 stimulate testosterone production by goldfish testis in vitro, Gen. Comp. Endocr. 90 (1993) 109-118.

[67] M.G. Wade, G. Van der Kraak, Regulation of prostaglandin E and F production in the goldfish testis. Vol. 266, Wiley Subscription Services, Inc., A Wiley Company, 1993, pp. 108-115.

[68] M.G. Wade, G. Van der Kraak, M.F. Gerrits, J.S. Ballantyne, Release and steroidogenic action of polyunsaturated fatty acids in the goldfish testis, Biol. Reprod. 51 (1994) 131-139.

[69] X. Wang, D.M. Stocco, Cyclic AMP and arachidonic acid: a tale of two pathways, Mol. Cell. Endocrinol. 158 (1999) 7-12.

[70] X. Wang, D.M. Stocco, The decline in testosterone biosynthesis during male aging: A consequence of multiple alterations, Mol. Cell. Endocrinol. 238 (2005) 1-7. 
Fig. 1 ARA levels in red blood cells (\% TFA) of six (A, B, C, D, E F) fish groups of Senegalese sole (Solea senegalensis) fed different dietary ARA levels over nine months. Fish are grouped by sex in Fig 1a) males and Fig 1 b) females. Different letters for the same month indicate significant differences (ANOVA, $P<0.05, N=10$ ) among groups. ARA content, diet $A=0.7, B=$ 1.6, $C=2.3, D=3.2, E=5.0$ and $F=6.0 \% T F A$.

Fig. 2 EPA/ARA ratio in red blood cells of six groups $(A, B, C, D, E, F)$ of Senegalese sole (Solea senegalensis) fed different dietary ARA levels over nine months. The fish were sampled in September (Sep.), December (Dec.), March and May. Fish are grouped by sex in Fig 2a) males and Fig 2b) females. Values are mean \pm SEM significant differences between groups were established by one-way ANOVA and are indicated by different superscripts for each month $(P<0.05, N=10)$. ARA content, diet $A=0.7, B=1.6, C=2.3, D=3.2, E=5.0$ and $F=6.0 \%$ TFA.

Fig. 3 Cholesterol (CHOL) levels in the blood of six fish groups of Senegalese sole, males and females fed different dietary ARA levels (A, B, C, D, E and F), over nine month (SeptemberMay). Values are mean + SEM and are expressed as \% of total lipids. Columns assigned different letters were significantly different (ANOVA, $P<0.05, N=10$ ). ARA content, diet A=0.7, $B=1.6, C=2.3, D=3.2, E=5.0$ and $F=6.0 \%$ TFA.

Fig. 4 Concentration of plasma prostaglandins a) E-isomers, PGE2 and PGE3 and b) Fisomers, PGF $2 \alpha$ and PGF3 $\alpha$, of six groups of Senegalese sole females fed over nine month with different dietary ARA levels $(A, B, C, D, E$ and $F)$. Values are mean + SEM and are expressed as pg $\mathrm{ml}^{-1}$ plasma, significant differences between groups were established by one-way ANOVA and are indicated by different superscript letters within individual bars $(P<0.05, N=10)$. ARA content, diet $A=0.7, B=1.6, C=2.3, D=3.2, E=5.0$ and $F=6.0 \%$ TFA.

Fig. 5 Concentration of plasma prostaglandins a) E-isomers, PGE2 and PGE3 and b) Fisomers, PGF2 $\alpha$ and PGF3 $\alpha$, of six groups of Senegalese sole males, fed over nine months with different dietary ARA levels $(A, B, C, D, E$ and $F)$. Values are mean $+S E M$ are expressed as $p g$ $\mathrm{ml}^{-1}$ plasma, significant differences between groups were established by one-way ANOVA and are indicated by different superscript letters within individual bars $(P<0.05, N=10)$. ARA content, diet $A=0.7, B=1.6, C=2.3, D=3.2, E=5.0$ and $F=6.0 \%$ TFA.

Fig. 6 Changes in plasma levels of 11-ketotestosterone (11-KT) and testosterone (T) (mean \pm SEM) of Senegalese sole males measured in December 2009 (Dec.), January (Jan.), February (Feb.), March (Mar.), April (Apr.), May and June 2010 and fed different dietary ARA levels. a) Fish fed diets $A$ and $B, b)$ fish fed diets $A$ and $C, c)$ fish fed diets $A$ and $D, d$ ) fish fed diets $A$ and $E$, e) fish fed diets $A$ and $F$. Different letters indicate significant differences (ANOVA, $P<0.05$, $N=10)$ between sampling months and within treatments. Small letters are used for diet $A$ used as a control and capital letters for dietary treatments $B, C, D, E$ and $F$. (*) indicate significant differences $(P<0.05)$ with respect to the control group $(A)$ and the dietary treatment. ARA content, diet $A=0.7$ (control), $B=1.6, C=2.3, D=3.2, E=5.0, F=6.0 \% T F A$. 
629

630

631

632

633

634

635

636

637

638

639

640

641

642

643

644

645

646

647

648

649

650

651

652

653

654

655

656

657

658

659

660

661 59

61

Fig. 7 Changes in plasma levels of estradiol (E2) (mean \pm SEM) of Senegalese sole females measured in December 2009 (Dec.), January (Jan.), February (Feb.), March (Mar.), April (Apr.), May and June 2010 and fed different dietary ARA levels. a) Fish fed diets A and B, b) fish fed diets $A$ and $C, c)$ fish fed diets $A$ and $D, d$ ) fish fed diets $A$ and $E, e)$ fish fed diets $A$ and $F$. Different letters indicate significant differences (ANOVA, $P<0.05, N=10$ ) between sampling months and within treatments. Small letters are used for diet A used as a control and capital letters for dietary treatments $B, C, D, E$ and $F .(*)$ indicate significant differences $(P<0.05)$ with respect to the control group (A) and the dietary treatment. ARA content, diet $A=0.7$ (control), $B=1.6, C=2.3, D=3.2, E=5.0, F=6.0 \% T F A$.

Table 1 Ingredients and chemical composition of six experimental diets $(A, B, C, D, E$ and $F)$

Table 2 Lipid, fatty acid content and fatty acid composition (\% TFA \pm SEM) of the diets used (A, $B, C, D, E$ and $F)$ to feed G1 Senegalese sole (Solea senegalensis). Rows assigned different letters were significantly different (ANOVA, $P<0.05, N=3$ )

Table 3 Lipid class composition (\% \pm SEM) of the diets used (A, B, C, D, E and F) to feed G1 Senegalese sole (Solea senegalensis) (ANOVA, $P<0.05, N=10)$.

Table 4 Lipid, fatty acid content and fatty acid composition (\% TFA) of Senegalese sole male blood sampled in September 2009 (Initial), and in May 2010 (Final) and fed 6 different diets (A, $B, C, D, E, F)$. Rows assigned different letters were significantly different (ANOVA, $P<0.05$, $N=10$ ). ARA content, diet $A=0.7, B=1.6, C=2.3, D=3.2, E=5.0$ and $F=6.0 \% T F A$

Table 5 Lipid, fatty acid content and fatty acid composition (\% TFA) of Senegalese sole female blood sampled in September 2009 (Initial), and in May 2010 (Final) and fed six different diets $(A, B, C, D, E, F)$. Rows assigned different letters were significantly different (ANOVA, $P<0.05$, $N=10$ ). ARA content, diet $A=0.7, B=1.6, C=2.3, D=3.2, E=5.0$ and $F=6.0 \% T F A$ (1)

\section{6}

(1)

\section{8} 60 
Fig. 1

664

665

666

667

668

669

670

671

672

673

\section{Male - ARA}

Sep. Dec. March May

(a)

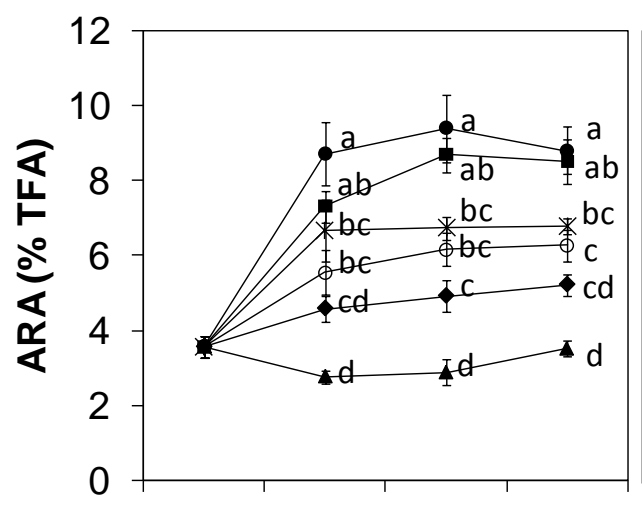

\section{Female - ARA}

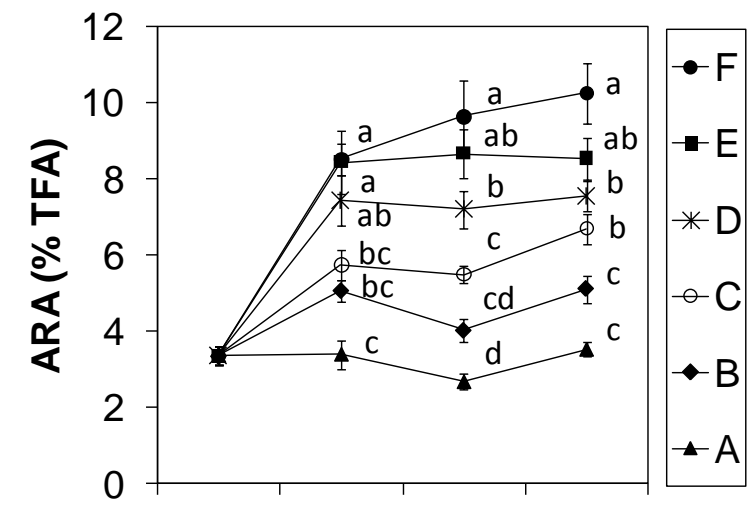

Sep. Dec. March May

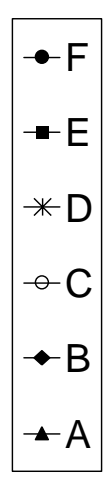

(b)
Female - EPA/ARA (a)

Male - EPA/ARA

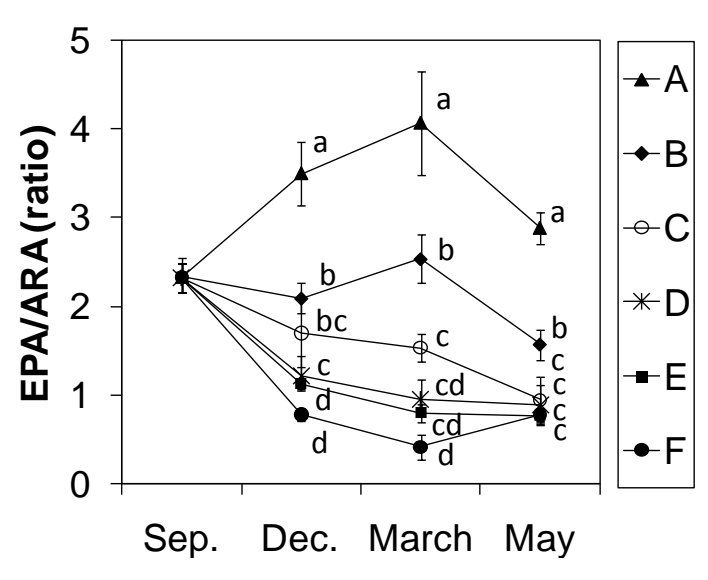

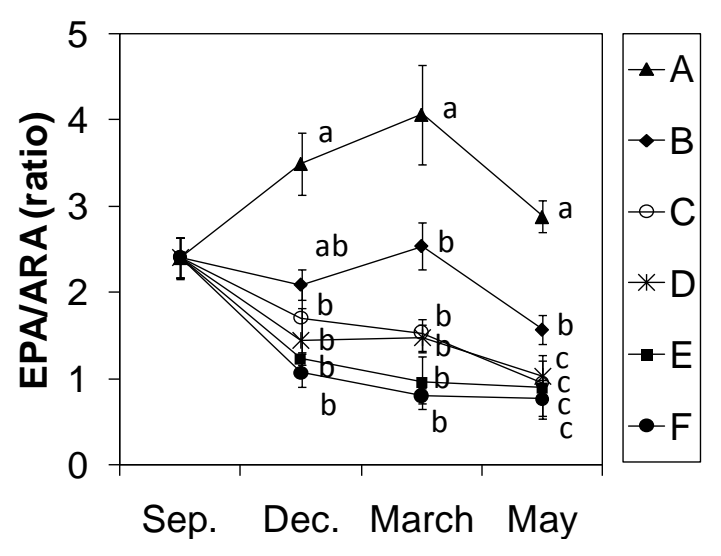

Fig. 2 
$674 \quad$ Fig. 3

\section{CHOL in blood}

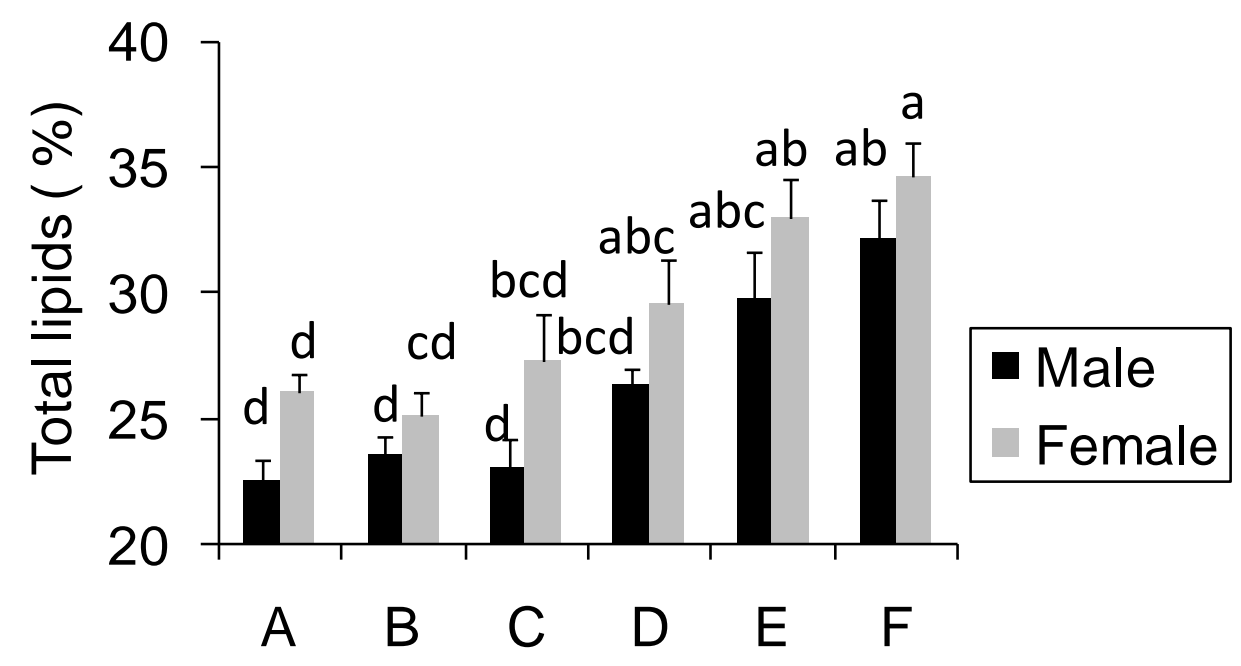

675

676

677

678

679

680

681

682

683

684

685

686

687

688

689

690

691 
PGs E-isomers

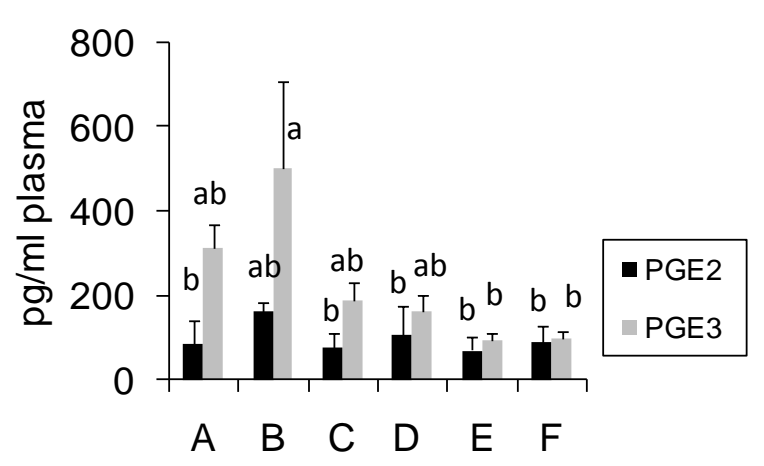

PGs F-isomers

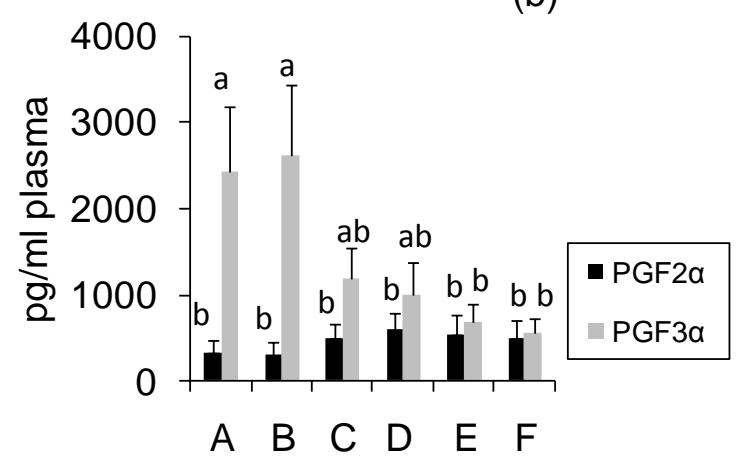

694

695

696

697

698

699

700

701

702

703

704

705

706

707

708

709

710

711

Fig. 5

PGs E-isomers

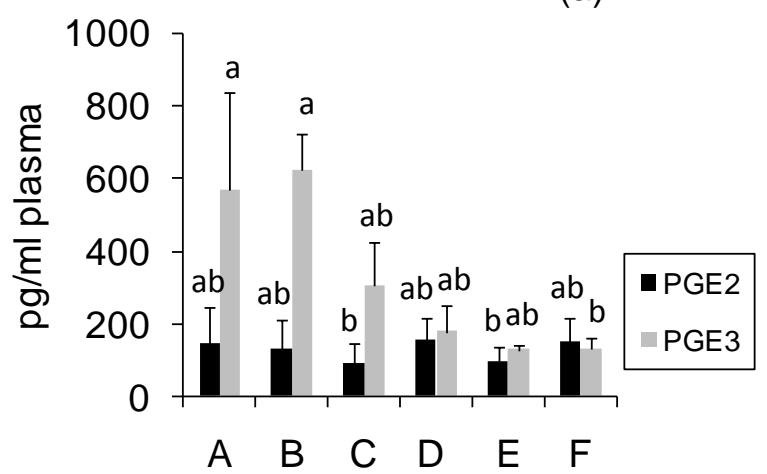

PGs F-isomers

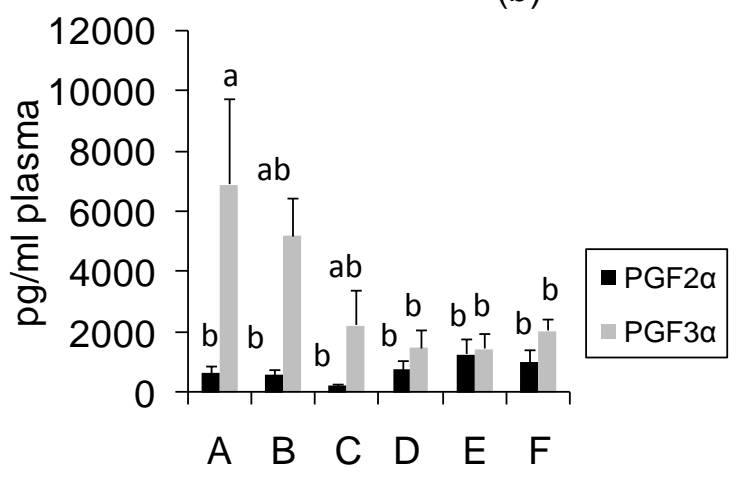


Fig. 6

Ketotestosterone (11-KT)

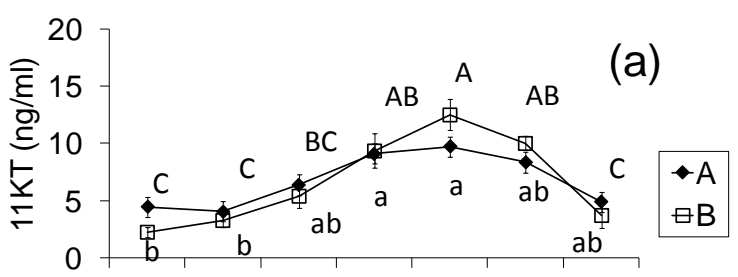

(b)

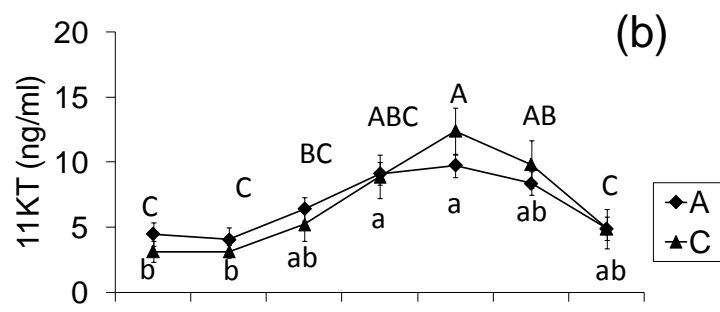

(c)

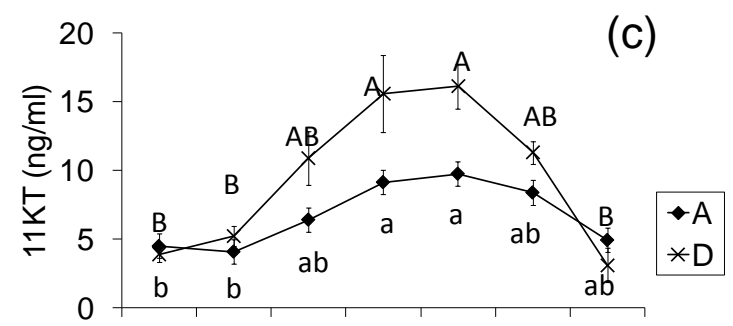

(d)

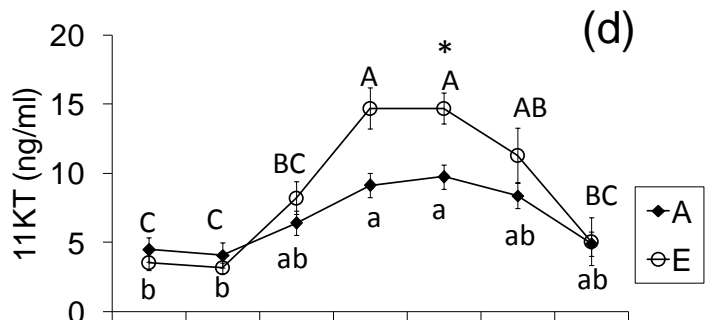

(e)

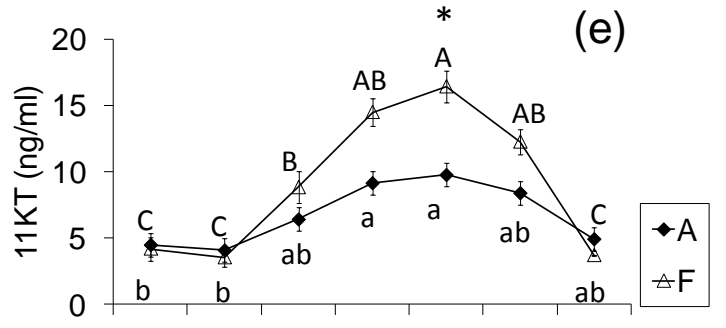

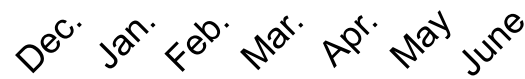

Testosterone (T)

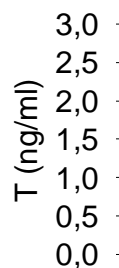

(a)
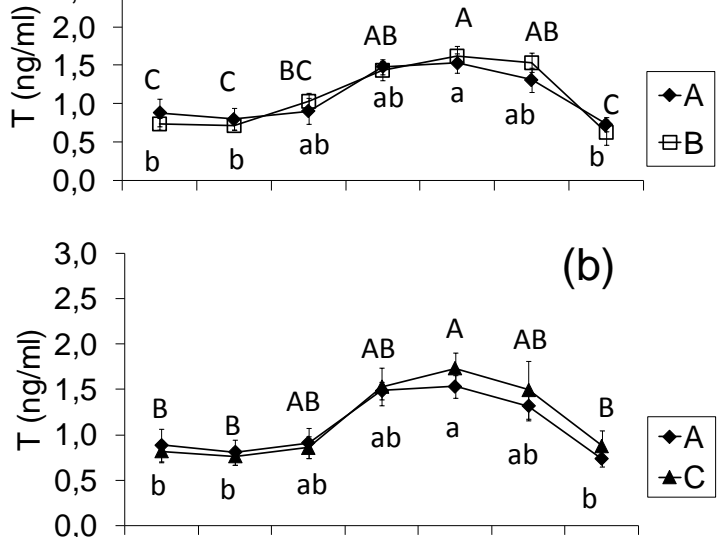

(b)
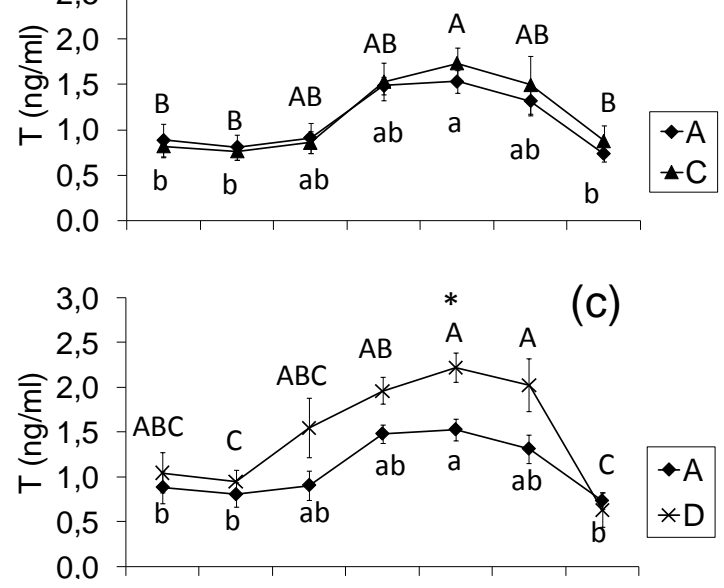

(d)
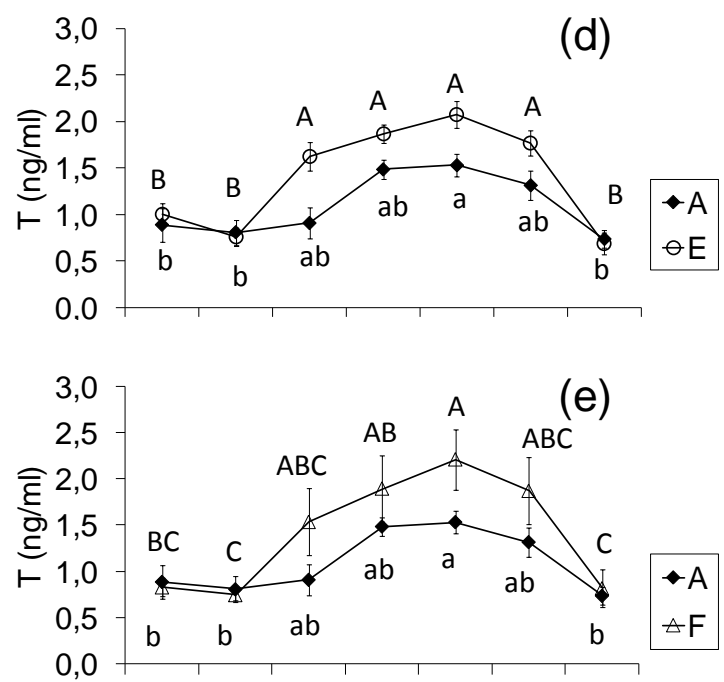

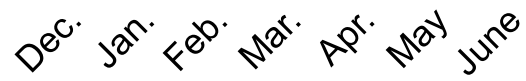


Fig. 7

719

Estradiol (E2)
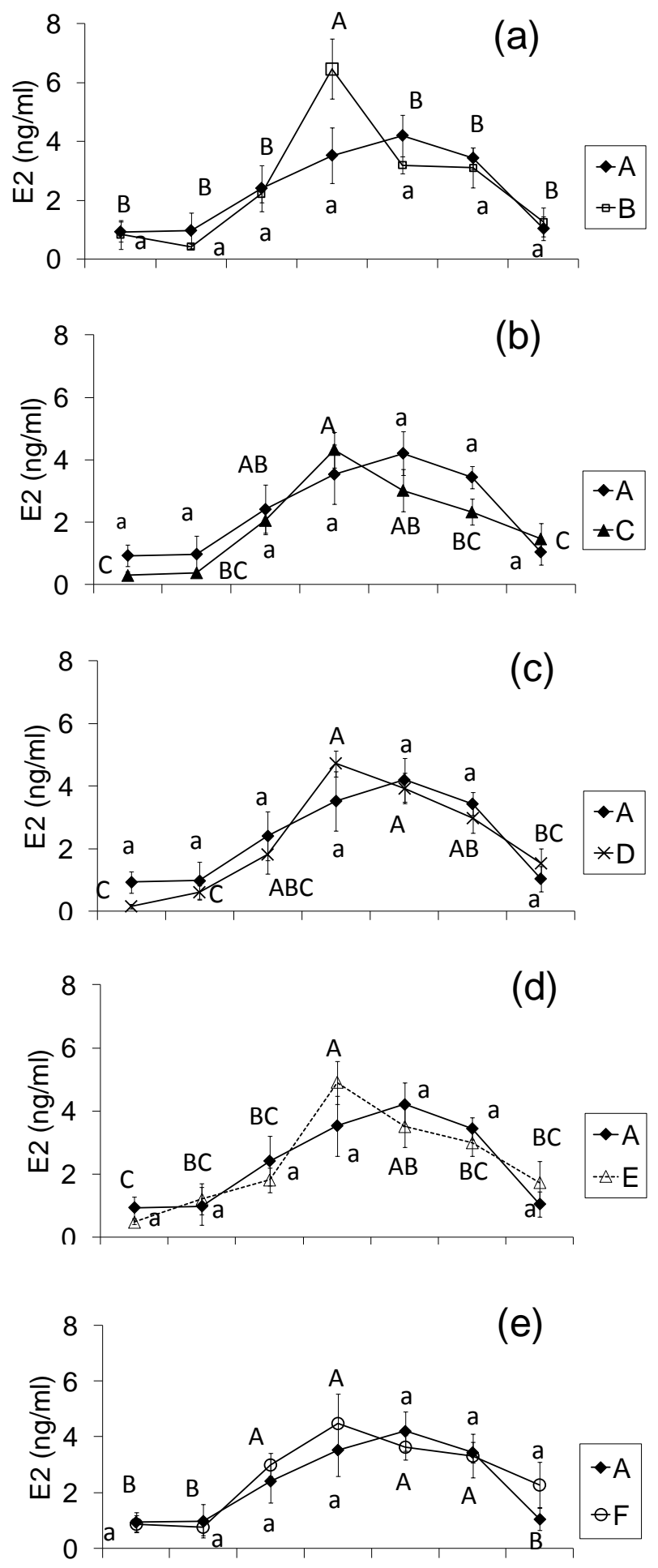
721 Table 1

\begin{tabular}{lrrrrrr} 
Ingredients $(\mathrm{g} / \mathrm{Kg})$ & $\mathrm{A}$ & $\mathrm{B}$ & $\mathrm{C}$ & $\mathrm{D}$ & $\mathrm{E}$ & $\mathrm{F}$ \\
\hline Fish meal $^{1}$ & 645.0 & 645.0 & 645.0 & 645.0 & 645.0 & 645.0 \\
Wheat gluten $^{2}$ & 120.0 & 120.0 & 120.0 & 120.0 & 120.0 & 120.0 \\
Wheat $^{3}$ & 125.8 & 125.8 & 125.8 & 125.8 & 125.8 & 125.8 \\
Fish oil $^{4}$ & 80.0 & 76.0 & 71.8 & 67.6 & 63.2 & 59.0 \\
Vevodar $^{5}$ & 0.0 & 4.0 & 8.2 & 12.4 & 16.8 & 21.0 \\
Premixes $^{6}$ & 29.2 & 29.2 & 29.2 & 29.2 & 29.2 & 29.2
\end{tabular}

Analysed values

Moisture, $\%$

Crude protein, $\% \mathrm{DM}^{7}$

\begin{tabular}{rrrrrr}
8.0 & 7.8 & 8.3 & 8.4 & 8.6 & 8.3 \\
61,2 & 61,4 & 61,6 & 61,7 & 61,8 & 62,2 \\
13.8 & 14.1 & 14.4 & 13.7 & 14.1 & 14.3 \\
\hline
\end{tabular}

722 Crude fat, \% DM

${ }^{2}$ LT fish meal, Skretting, Stavanger, Norway

$724 \quad{ }^{2}$ Cargill Nordic, Charlottenlund, Denmark

$725{ }^{3}$ Skretting, Stavanger, Norway

$726 \quad{ }^{4}$ Scandinavian fish oil, Skretting, Stavanger, Norway

$727{ }^{5}$ Contains 35\% arachidonic acid, DSM Food Specialities, Delft, The Netherlands

$728{ }^{6}$ Include micro nutrients, vitamin and mineral supplementation. Trouw Nutrition, Boxmeer,

729 the Netherlands, proprietary composition Skretting ARC

$730 \quad{ }^{7}$ Dry matter

731

732

733

734

735

736

737

738

739

740

741

742 
Table 2

\begin{tabular}{|c|c|c|c|c|c|c|c|c|c|c|c|c|c|c|c|c|c|c|c|c|c|c|c|c|}
\hline \multirow[b]{2}{*}{$\operatorname{TFA}\left(\mu \mathrm{g} \mathrm{mg}^{-1} \mathrm{~L}\right)$} & \multicolumn{4}{|c|}{ A } & \multicolumn{3}{|c|}{ B } & & \multicolumn{3}{|c|}{$\mathrm{C}$} & \multicolumn{4}{|c|}{$\mathrm{D}$} & & \multicolumn{3}{|c|}{$\mathrm{E}$} & \multicolumn{4}{|c|}{$\mathrm{F}$} & \\
\hline & 880 & \pm & 87 & & 702 & \pm & 34 & & 820 & \pm & 74 & & 861 & \pm & 82 & & 961 & \pm & 19 & & 911 & \pm & 94 & \\
\hline \multicolumn{25}{|c|}{ Fatty acid composition (\%TFA) } \\
\hline 14:0 & 2.5 & \pm & 1.2 & & 3.6 & \pm & 2.8 & & 3.8 & \pm & 2.1 & & 3.6 & \pm & 2.3 & & 3.7 & \pm & 2.8 & & 4.0 & \pm & 2.9 & \\
\hline $16: 0$ & 14.9 & \pm & 1.1 & & 15.3 & \pm & 3.7 & & 17.6 & \pm & 2.6 & & 15.8 & \pm & 1.8 & & 15.0 & \pm & 2.8 & & 16.1 & \pm & 2.7 & \\
\hline 18:0 & 1.8 & \pm & 0.9 & & 2.4 & \pm & 0.9 & & 2.6 & \pm & 0.7 & & 2.6 & \pm & 0.6 & & 3.0 & \pm & 0.7 & & 3.2 & \pm & 0.4 & \\
\hline Total SFA & 19.4 & \pm & 1.5 & & 21.7 & \pm & 5.7 & & 24.4 & \pm & 4.2 & & 22.3 & \pm & 3.6 & & 21.9 & \pm & 4.8 & & 23.4 & \pm & 5.2 & \\
\hline $16: 1 n-7$ & 4.9 & \pm & 0.8 & & 4.8 & \pm & 2.0 & & 5.0 & \pm & 0.8 & & 4.9 & \pm & 0.8 & & 4.3 & \pm & 1.8 & & 4.4 & \pm & 1.2 & \\
\hline $18: 1 n-9$ & 15.0 & \pm & 1.3 & & 15.7 & \pm & 2.4 & & 16.9 & \pm & 1.9 & & 15.9 & \pm & 2.0 & & 15.1 & \pm & 2.7 & & 15.7 & \pm & 0.6 & \\
\hline $18: 1 n-7$ & 1.2 & \pm & 2.0 & & 0.9 & \pm & 1.6 & & 1.0 & \pm & 1.7 & & 0.8 & \pm & 1.4 & & 0.8 & \pm & 1.4 & & 1.0 & \pm & 1.7 & \\
\hline $20: 1 n-9$ & 7.2 & \pm & 1.5 & & 7.1 & \pm & 0.3 & & 7.2 & \pm & 1.1 & & 6.3 & \pm & 0.5 & & 6.9 & \pm & 0.7 & & 6.6 & \pm & 0.4 & \\
\hline $22: 1 n-9$ & 3.5 & \pm & 6.0 & & 3.9 & \pm & 6.7 & & 2.9 & \pm & 5.0 & & 3.0 & \pm & 5.2 & & 3.9 & \pm & 6.7 & & 2.9 & \pm & 5.1 & \\
\hline Total MUFA & 32.3 & \pm & 10.5 & & 32.7 & \pm & 4.7 & & 33.4 & \pm & 4.4 & & 31.3 & \pm & 4.9 & & 31.4 & \pm & 5.5 & & 31.1 & \pm & 6.0 & \\
\hline $18: 2 n-6$ & 5.9 & \pm & 0.7 & & 6.4 & \pm & 0.7 & & 6.0 & \pm & 0.9 & & 6.6 & \pm & 0.4 & & 5.9 & \pm & 0.1 & & 7.2 & \pm & 0.7 & \\
\hline $20: 4 n-6$, ARA & 0.7 & \pm & 0.3 & c & 1.6 & \pm & 0.6 & c & 2.3 & \pm & 0.8 & $\mathrm{bc}$ & 3.2 & \pm & 0.7 & b & 5.0 & \pm & 0.6 & a & 6.0 & \pm & 0.1 & a \\
\hline $22: 4 n-6$ & 0.1 & \pm & 0.1 & & 0.0 & \pm & 0.0 & & 0.0 & \pm & 0.0 & & 0.0 & \pm & 0.0 & & 0.0 & \pm & 0.0 & & 0.0 & \pm & 0.0 & \\
\hline $22: 5 n-6$ & 0.3 & \pm & 0.6 & & 0.3 & \pm & 0.2 & & 0.2 & \pm & 0.3 & & 0.2 & \pm & 0.3 & & 0.2 & \pm & 0.2 & & 0.3 & \pm & 0.4 & \\
\hline Total n-6 PUFA & 9.3 & \pm & 3.4 & & 8.4 & \pm & 1.3 & & 8.9 & \pm & 1.5 & & 10.6 & \pm & 0.8 & & 12.4 & \pm & 1.0 & & 14.0 & \pm & 1.6 & \\
\hline $18: 3 n-3$ & 1.3 & \pm & 0.2 & & 1.4 & \pm & 0.2 & & 1.3 & \pm & 0.3 & & 1.3 & \pm & 0.2 & & 1.2 & \pm & 0.1 & & 1.2 & \pm & 0.1 & \\
\hline $18: 4 n-3$ & 2.2 & \pm & 0.3 & & 2.0 & \pm & 0.1 & & 1.8 & \pm & 0.3 & & 2.0 & \pm & 0.1 & & 1.8 & \pm & 0.2 & & 1.7 & \pm & 0.2 & \\
\hline $20: 4 n-3$ & 0.7 & \pm & 0.1 & & 0.7 & \pm & 0.1 & & 0.6 & \pm & 0.1 & & 0.7 & \pm & 0.0 & & 0.6 & \pm & 0.1 & & 0.6 & \pm & 0.1 & \\
\hline 20:5n-3, EPA & 13.0 & \pm & 8.4 & & 16.8 & \pm & 5.3 & & 15.9 & \pm & 5.4 & & 16.4 & \pm & 5.4 & & 14.8 & \pm & 6.0 & & 14.7 & \pm & 4.9 & \\
\hline $22: 5 n-3$, DPA & 1.6 & \pm & 0.4 & & 3.0 & \pm & 2.3 & & 2.0 & \pm & 1.0 & & 2.3 & \pm & 1.3 & & 4.6 & \pm & 5.7 & & 2.0 & \pm & 0.9 & \\
\hline $22: 6 n-3$, DHA & 14.4 & \pm & 2.0 & & 13.0 & \pm & 2.1 & & 11.3 & \pm & 2.5 & & 13.0 & \pm & 1.6 & & 11.1 & \pm & 0.6 & & 11.3 & \pm & 2.3 & \\
\hline Total n-3 PUFA & 39.0 & \pm & 11.0 & & 37.1 & \pm & 0.7 & & 33.4 & \pm & 2.9 & & 35.8 & \pm & 2.1 & & 34.3 & \pm & 1.9 & & 31.5 & \pm & 1.4 & \\
\hline Total PUFA & 48.3 & \pm & 11.2 & & 45.5 & \pm & 1.4 & & 42.3 & \pm & 2.6 & & 46.4 & \pm & 1.4 & & 46.6 & \pm & 2.0 & & 45.5 & \pm & 1.7 & \\
\hline EPA/ARA & 23.6 & \pm & 18.2 & a & 12.4 & \pm & 6.6 & a & 7.8 & \pm & 4.2 & $\mathrm{ab}$ & 5.5 & \pm & 2.5 & ab & 3.0 & \pm & 1.3 & b & 2.4 & \pm & 0.8 & b \\
\hline EPA/DHA & 0.9 & \pm & 0.5 & & 1.3 & \pm & 0.6 & & 1.5 & \pm & 0.8 & & 1.3 & \pm & 0.5 & & 1.3 & \pm & 0.6 & & 1.4 & \pm & 0.7 & \\
\hline DHA/ARA & 23.5 & \pm & 9.0 & a & 8.8 & \pm & 1.6 & b & 5.1 & \pm & 1.1 & bc & 4.1 & \pm & 0.5 & bc & 2.2 & \pm & 0.3 & $\mathrm{bc}$ & 1.9 & \pm & 0.4 & c \\
\hline$n-3 / n-6$ & 4.6 & \pm & 2.3 & & 4.5 & \pm & 0.7 & & 3.8 & \pm & 0.8 & & 3.4 & \pm & 0.4 & & 2.8 & \pm & 0.3 & & 2.3 & \pm & 0.3 & \\
\hline
\end{tabular}

TL: total lipids, L: lipids, TFA: total fatty acids, DW: dry weigh, SFA: total saturated fatty acids, MUFA: total monounsaturated fatty acids, PUFA: total polyunsaturated fatty acids, ARA: arachidonic acid, EPA: eicosapentaenoic acid, DHA: docosahexaenoic acid, SEM: standard error of the mean. 
752

\begin{tabular}{|l|r|r|r|r|r|r|}
\hline & \multicolumn{1}{|c|}{$\mathrm{A}$} & \multicolumn{1}{c|}{$\mathrm{B}$} & \multicolumn{1}{c|}{$\mathrm{C}$} & \multicolumn{1}{c|}{$\mathrm{D}$} & \multicolumn{1}{c|}{$\mathrm{E}$} & \multicolumn{1}{c|}{$\mathrm{F}$} \\
\hline PC & $11.0 \pm 0.4$ & $12.2 \pm 0.1$ & $11.6 \pm 0.3$ & $11.1 \pm 0.3$ & $10.2 \pm 0.4$ & $10.6 \pm 0.0$ \\
\hline PS/PI & $0.0 \pm 0.0$ & $0.0 \pm 0.0$ & $0.0 \pm 0.0$ & $0.0 \pm 0.0$ & $0.0 \pm 0.0$ & $0.0 \pm 0.0$ \\
\hline PE & $3.4 \pm 0.1$ & $3.2 \pm 0.0$ & $3.3 \pm 0.2$ & $3.3 \pm 0.2$ & $5.2 \pm 0.0$ & $4.2 \pm 0.6$ \\
\hline Total PL & $14.3 \pm 0.1$ & $15.4 \pm 0.2$ & $14.9 \pm 0.1$ & $14.3 \pm 0.3$ & $15.4 \pm 0.3$ & $14.8 \pm 0.6$ \\
\hline CHOL & $11.9 \pm 0.8$ & $12.3 \pm 0.9$ & $12.5 \pm 0.8$ & $11.1 \pm 0.7$ & $13.3 \pm 0.6$ & $11.2 \pm 0.1$ \\
\hline FFA & $2.9 \pm 0.4$ & $3.8 \pm 0.5$ & $3.3 \pm 0.6$ & $3.6 \pm 0.3$ & $4.3 \pm 0.5$ & $4.0 \pm 0.1$ \\
\hline TAG & $61.5 \pm 0.3$ & $60.2 \pm 0.4$ & $60.8 \pm 0.5$ & $62 \pm 0.7$ & $59 \pm 0.6$ & $60 \pm 0.2$ \\
\hline SE+W & $10.4 \pm 0.6$ & $9.32 \pm 0.6$ & $9.9 \pm 0.6$ & $9.2 \pm 0.9$ & $9.8 \pm 0.4$ & $9.5 \pm 0.4$ \\
\hline Total NL & $86.7 \pm 0.5$ & $85.6 \pm 0.2$ & $86.5 \pm 0.2$ & $85.7 \pm 0.2$ & $86.6 \pm 0.2$ & $85.2 \pm 0.7$ \\
\hline
\end{tabular}
polar lipids, CHOL: cholesterol, FFA: free fatty acids, TAG: triacylglycerides, SE+W: sterol ester plus wax and NL: neutral lipids.

761

762

763

764

765

766

767

768

769

770

771

772

773 


\begin{tabular}{|c|c|c|c|c|c|c|c|}
\hline & $\begin{array}{l}\text { Initial } \\
\text { Sept. }\end{array}$ & $\begin{array}{c}\text { Final } \\
\text { A }\end{array}$ & $\begin{array}{c}\text { Final } \\
\text { B } \\
\end{array}$ & $\begin{array}{c}\text { Final } \\
\mathrm{C} \\
\end{array}$ & $\begin{array}{c}\text { Final } \\
\text { D } \\
\end{array}$ & $\begin{array}{c}\text { Final } \\
\text { E }\end{array}$ & $\begin{array}{c}\text { Final } \\
\mathrm{F} \\
\end{array}$ \\
\hline & $0 \pm 1.6^{\mathrm{a}}$ & $8.6 \pm 0.5^{\mathrm{a}}$ & $8.0 \pm 0.5^{\mathrm{a}}$ & $8.9 \pm 1.1^{\mathrm{a}}$ & $7.8 \pm 1.2^{\mathrm{a}}$ & $8.4 \pm 0.6^{\mathrm{a}}$ & $8.7 \pm 0.9^{\mathrm{a}}$ \\
\hline & $8 \pm 11^{a}$ & $408 \pm 21^{\mathrm{a}}$ & $387 \pm 13^{a}$ & $359 \pm 23^{a}$ & $374 \pm 23^{a}$ & $399 \pm 47^{\mathrm{a}}$ & $323 \pm 19^{a}$ \\
\hline \multicolumn{8}{|c|}{ Fatty acid composition (\% TFA) } \\
\hline $14: 0$ & $1.4 \pm 0.1^{\mathrm{a}}$ & $1.2 \pm 0.1^{\mathrm{a}}$ & $1.0 \pm 0.1^{\mathrm{a}}$ & $1.1 \pm 0.2^{\mathrm{a}}$ & $0.7 \pm 0.1^{\mathrm{a}}$ & $1.0 \pm 0.1^{\mathrm{a}}$ & $1.1 \pm 0.1^{\mathrm{b}}$ \\
\hline 16 & $15.0 \pm 0.3^{\mathrm{a}}$ & $14.7 \pm 0.4^{\mathrm{a}}$ & $14.1 \pm 0.7^{\mathrm{a}}$ & $14.9 \pm 0.5^{\mathrm{a}}$ & $14.8 \pm 0.6^{\mathrm{a}}$ & $13.6 \pm 0.5^{\mathrm{a}}$ & $14.9 \pm 0.5^{\mathrm{a}}$ \\
\hline 18:0 & $8.7 \pm 0.4^{\mathrm{a}}$ & $8.1 \pm 0.4^{\mathrm{a}}$ & $8.1 \pm 0.2^{\mathrm{a}}$ & $8.4 \pm 0.7^{\mathrm{a}}$ & $8.9 \pm 0.5^{\mathrm{a}}$ & $9.0 \pm 0.4^{\mathrm{a}}$ & $9.7 \pm 0.5^{\mathrm{a}}$ \\
\hline Tot & $28.0 \pm 0.6^{\mathrm{a}}$ & $24.4 \pm 0.8^{b}$ & $23.5 \pm 0.9^{b}$ & $24.6 \pm 0.5^{b}$ & $24.6 \pm 0.7^{b}$ & $24.2 \pm 0.6^{\mathrm{b}}$ & $26.1 \pm 0.9^{\mathrm{a}}$ \\
\hline $16: 1 n-7$ & $2.1 \pm 0.2^{\mathrm{a}}$ & $2.1 \pm 0.3^{\mathrm{a}}$ & $2.2 \pm 0.1^{\mathrm{a}}$ & $2.1 \pm 0.4^{\mathrm{a}}$ & $1.8 \pm 0.3^{\mathrm{a}}$ & $1.9 \pm 0.2^{\mathrm{a}}$ & $2.5 \pm 0.2^{\mathrm{a}}$ \\
\hline 18 & $16.2 \pm 0.7^{\mathrm{a}}$ & $12.6 \pm 1.5^{b}$ & $12.5 \pm 0.5^{b}$ & $13.5 \pm 0.6^{\mathrm{ab}}$ & $14.2 \pm 0.5^{\mathrm{ab}}$ & $11.9 \pm 0.5^{b}$ & $13.6 \pm 0.9^{a b}$ \\
\hline & $0.5 \pm 0.5^{b}$ & $3.6 \pm 1.1^{\mathrm{a}}$ & $2.4 \pm 0.1^{\mathrm{ab}}$ & $2.1 \pm 0.3^{a b}$ & $1.2 \pm 0.4^{b}$ & $1.7 \pm 0.3^{\mathrm{ab}}$ & $1.5 \pm 0.3^{\mathrm{ab}}$ \\
\hline & $.4 \pm 0.2^{b}$ & $4.2 \pm 0.3^{\mathrm{a}}$ & $4.0 \pm 0.2^{\mathrm{a}}$ & $3.8 \pm 0.5^{\mathrm{a}}$ & $3.9 \pm 0.4^{\mathrm{a}}$ & $4.0 \pm 0.4^{\mathrm{a}}$ & $3.4 \pm 0.5^{\mathrm{a}}$ \\
\hline $22: 1 n-9$ & $0.0 \pm 0.0^{\mathrm{a}}$ & $0.0 \pm 0.0^{\mathrm{a}}$ & $0.0 \pm 0.0^{\mathrm{a}}$ & $0.0 \pm 0.0^{\mathrm{a}}$ & $0.0 \pm 0.0^{\mathrm{a}}$ & $0.0 \pm 0.0^{\mathrm{a}}$ & $0.0 \pm 0.0^{\mathrm{a}}$ \\
\hline Tot: & $20.2 \pm 0.6^{\mathrm{a}}$ & $22.7 \pm 1.0^{\mathrm{a}}$ & $21.3 \pm 0.8^{\mathrm{a}}$ & $21.5 \pm 1.4^{\mathrm{a}}$ & $20.7 \pm 0.7^{\mathrm{a}}$ & $19.5 \pm 0.8^{\mathrm{a}}$ & $21.5 \pm 0.9^{\mathrm{a}}$ \\
\hline $18: 2 n-6$ & $7.5 \pm 0.2^{a}$ & $5.8 \pm 0.2^{b}$ & $5.1 \pm 0.3^{b}$ & $5.6 \pm 0.4^{b}$ & $5.7 \pm 0.2^{b}$ & $4.7 \pm 0.2^{b}$ & $5.3 \pm 0.3^{b}$ \\
\hline $20: 4 n-6$ & $3.6 \pm 0.3^{c}$ & $3.5 \pm 0.2^{c}$ & $5.2 \pm 0.3^{b}$ & $6.3 \pm 0.4^{b}$ & $6.8 \pm 0.2^{b}$ & $8.5 \pm 0.6^{\mathrm{a}}$ & $8.7 \pm 0.6^{\mathrm{a}}$ \\
\hline $22: 4 n-6$ & $0.2 \pm 0.0^{f}$ & $0.4 \pm 0.0^{\mathrm{ef}}$ & $0.6 \pm 0.0^{\mathrm{de}}$ & $0.9 \pm 0.1^{\mathrm{cd}}$ & $1.0 \pm 0.1^{\mathrm{c}}$ & $1.4 \pm 0.1^{\mathrm{b}}$ & $1.6 \pm 0.1^{\mathrm{a}}$ \\
\hline & $.4 \pm 0.0^{c}$ & $0.6 \pm 0.1^{b c}$ & $0.7 \pm 0.1^{a b c}$ & $0.7 \pm 0.1^{a b}$ & $0.9 \pm 0.1^{a b}$ & $0.9 \pm 0.1^{a b}$ & $0.9 \pm 0.0^{\mathrm{a}}$ \\
\hline $\mathrm{H}$ & $12.1 \pm 0.4^{\mathrm{cd}}$ & $10.3 \pm 0.3^{\mathrm{d}}$ & $11.7 \pm 0.4^{\mathrm{cd}}$ & $13.9 \pm 0.4^{b c}$ & $14.8 \pm 0.4^{a b}$ & $16.7 \pm 0.6^{\mathrm{a}}$ & $16.7 \pm 0.9^{\mathrm{a}}$ \\
\hline$n-3$ & $0.4 \pm 0.0^{\mathrm{a}}$ & $0.2 \pm 0.1^{\mathrm{a}}$ & $0.1 \pm 0.1^{\mathrm{a}}$ & $0.2 \pm 0.1^{\mathrm{a}}$ & $0.1 \pm 0.1^{\mathrm{a}}$ & $0.2 \pm 0.1^{\mathrm{a}}$ & $0.2 \pm 0.1^{\mathrm{a}}$ \\
\hline & $0.7 \pm 0.0^{\mathrm{a}}$ & $0.6 \pm 0.2^{a b}$ & $0.2 \pm 0.0^{b}$ & $0.6 \pm 0.1^{a b}$ & $0.6 \pm 0.1^{a b}$ & $0.2 \pm 0.1^{b}$ & $0.3 \pm 0.2^{a b}$ \\
\hline $20: 4 n-3$ & $0.3 \pm 0.0^{\mathrm{a}}$ & $0.2 \pm 0.1^{\mathrm{a}}$ & $0.2 \pm 0.0^{\mathrm{a}}$ & $0.4 \pm 0.1^{\mathrm{a}}$ & $0.4 \pm 0.1^{\mathrm{a}}$ & $0.2 \pm 0.0^{\mathrm{a}}$ & $0.2 \pm 0.0^{\mathrm{a}}$ \\
\hline 20 & $7.8 \pm 0.2^{b}$ & $9.4 \pm 0.3^{a}$ & $8.6 \pm 0.3^{b}$ & $7.9 \pm 0.2^{b}$ & $7.7 \pm 0.3^{b}$ & $7.4 \pm 0.4^{b}$ & $7.3 \pm 0.6^{b}$ \\
\hline $22: 5 r$ & $6.2 \pm 0.3^{a}$ & $6.2 \pm 0.3^{\mathrm{ab}}$ & $6.6 \pm 0.4^{\mathrm{a}}$ & $5.5 \pm 0.4^{\mathrm{a}}$ & $5.5 \pm 0.4^{\mathrm{a}}$ & $5.3 \pm 0.2^{\mathrm{a}}$ & $4.6 \pm 0.5^{b}$ \\
\hline 22:6n-3, DHA & $21.3 \pm 0.7^{\mathrm{a}}$ & $23.9 \pm 1.1^{\mathrm{a}}$ & $22.3 \pm 1.2^{\mathrm{a}}$ & $21.0 \pm 1.1^{\mathrm{a}}$ & $22.2 \pm 1.0^{\mathrm{a}}$ & $21.1 \pm 0.6^{\mathrm{a}}$ & $21.0 \pm 0.9^{\mathrm{a}}$ \\
\hline A & $37.1 \pm 0.9^{\mathrm{ab}}$ & $40.6 \pm 1.4^{\mathrm{a}}$ & $38.0 \pm 1.6^{\mathrm{ab}}$ & $35.4 \pm 1.6^{a b c}$ & $36.6 \pm 1.4^{a b c}$ & $34.3 \pm 0.6^{b c}$ & $31.3 \pm 1.1^{\mathrm{c}}$ \\
\hline l PUFA & $49.2 \pm 0.8^{\mathrm{a}}$ & $50.9 \pm 1.4^{\mathrm{a}}$ & $49.6 \pm 1.7^{\mathrm{a}}$ & $49.3 \pm 1.8^{\mathrm{a}}$ & $51.5 \pm 1.4^{\mathrm{a}}$ & $51.0 \pm 0.8^{\mathrm{a}}$ & $48.0 \pm 1.5^{\mathrm{a}}$ \\
\hline 1 & $2.3 \pm 0.2^{\mathrm{a}}$ & $2.8 \pm 0.2^{\mathrm{a}}$ & $1.7 \pm 0.1^{b}$ & $1.3 \pm 0.1^{b}$ & $1.2 \pm 0.0^{b}$ & $0.8 \pm 0.1^{\mathrm{b}}$ & $0.9 \pm 0.1^{b}$ \\
\hline HA & $0.4 \pm 0.0^{\mathrm{a}}$ & $0.4 \pm 0.0^{\mathrm{a}}$ & $0.4 \pm 0.0^{\mathrm{a}}$ & $0.4 \pm 0.0^{\mathrm{a}}$ & $0.4 \pm 0.0^{\mathrm{a}}$ & $0.3 \pm 0.0^{\mathrm{a}}$ & $0.4 \pm 0.0^{\mathrm{a}}$ \\
\hline $\mathrm{RA}$ & $6.4 \pm 0.6^{\mathrm{a}}$ & $7.0 \pm 0.4^{\mathrm{a}}$ & $4.3 \pm 0.2^{b}$ & $3.4 \pm 0.2^{b}$ & $3.3 \pm 0.2^{b}$ & $2.4 \pm 0.2^{b}$ & $2.2 \pm 0.2^{b}$ \\
\hline $3 / \mathrm{n}-6$ & $3.1 \pm 0.1^{b c}$ & $4.0 \pm 0.2^{\mathrm{a}}$ & $3.2 \pm 0.2^{b}$ & $2.6 \pm 0.1^{\mathrm{cd}}$ & $2.5 \pm 0.1^{\mathrm{cd}}$ & $2.1 \pm 0.1^{\mathrm{d}}$ & $1.9 \pm 0.1^{\mathrm{d}}$ \\
\hline
\end{tabular}

TL: total lipids, L: lipids, TFA: total fatty acids, DW: dry weigh, SFA: total saturated fatty acids, MUFA: total monounsaturated fatty acids, PUFA: total polyunsaturated fatty acids, ARA: arachidonic acid, EPA: eicosapentaenoic acid, DHA: docosahexaenoic acid, SEM: standard error of the mean. 
Table 5

\begin{tabular}{|c|c|c|c|c|c|c|c|}
\hline & $\begin{array}{l}\text { Initial } \\
\text { Sept. }\end{array}$ & $\begin{array}{c}\text { Final } \\
\text { A }\end{array}$ & $\begin{array}{c}\text { Final } \\
\text { B } \\
\end{array}$ & $\begin{array}{c}\text { Final } \\
\mathrm{C} \\
\end{array}$ & $\begin{array}{c}\text { Final } \\
\text { D } \\
\end{array}$ & $\begin{array}{c}\text { Final } \\
\mathrm{E} \\
\end{array}$ & $\begin{array}{l}\text { inal } \\
\mathrm{F}\end{array}$ \\
\hline $\mathrm{TL}\left(\mathrm{mg} \mathrm{mL}^{-1}\right)$ & $8 \pm 1.6^{a}$ & $7.6 \pm 0.9^{\mathrm{a}}$ & $7.0 \pm 0.8^{\mathrm{a}}$ & $7.0 \pm 0.7^{\mathrm{a}}$ & $6.5 \pm 0.5^{\mathrm{a}}$ & $6.4 \pm 0.5^{\mathrm{a}}$ & $7.0 \pm 0.5^{\mathrm{a}}$ \\
\hline $\operatorname{TFA}\left(\mu \mathrm{g} \mathrm{mg}^{-1} \mathrm{~L}\right)$ & $210 \pm 19^{a}$ & $372 \pm 15^{b}$ & $354 \pm 10^{b}$ & $321 \pm 21$ & $315 \pm 15^{b}$ & $320 \pm 34^{b}$ & $336 \pm 30^{b}$ \\
\hline \multicolumn{8}{|c|}{ Fatty acid composition (\%TFA) } \\
\hline $14: 0$ & $1.6 \pm 0.2^{\mathrm{a}}$ & $1.3 \pm 0.2^{\mathrm{a}}$ & $1.1 \pm 0.1^{\mathrm{b}}$ & $0.7 \pm 0.1^{\mathrm{b}}$ & $0.6 \pm 0.1^{\mathrm{b}}$ & $1.1 \pm 0.1^{\mathrm{b}}$ & $1.0 \pm 0.1^{\mathrm{b}}$ \\
\hline $16: 0$ & $19.6 \pm 0.5^{\mathrm{a}}$ & $15.1 \pm 0.7^{\mathrm{a}}$ & $15.1 \pm 0.5^{\mathrm{a}}$ & $14.2 \pm 0.6^{\mathrm{a}}$ & $13.7 \pm 0.5^{\mathrm{a}}$ & $15.3 \pm 0.7^{\mathrm{a}}$ & $14.2 \pm 0.6^{\mathrm{a}}$ \\
\hline $18: 0$ & $9.5 \pm 0.5^{\mathrm{a}}$ & $8.3 \pm 0.5^{\mathrm{a}}$ & $8.2 \pm 0.4^{\mathrm{a}}$ & $9.5 \pm 0.4^{\mathrm{a}}$ & $9.4 \pm 0.4^{\mathrm{a}}$ & $9.8 \pm 0.9^{\mathrm{a}}$ & $8.7 \pm 0.5^{\mathrm{a}}$ \\
\hline $\mathrm{T}$ & $31.1 \pm 0.8^{\mathrm{a}}$ & $25.4 \pm 0.9^{b}$ & $24.8 \pm 0.7^{\mathrm{b}}$ & $24.8 \pm 0.9^{b}$ & $24.1 \pm 0.8^{b}$ & $26.7 \pm 1.3^{b}$ & $24.4 \pm 0.8^{b}$ \\
\hline 16: & $2.8 \pm 0.2^{\mathrm{a}}$ & $2.1 \pm 0.3^{\mathrm{a}}$ & $2.1 \pm 0.2^{\mathrm{a}}$ & $2.0 \pm 0.2^{\mathrm{a}}$ & $2.0 \pm 0.3^{\mathrm{a}}$ & $2.1 \pm 0.2^{\mathrm{a}}$ & $2.2 \pm 0.4^{\mathrm{a}}$ \\
\hline 18: & $16.9 \pm 0.7^{\mathrm{a}}$ & $13.5 \pm 0.4^{b}$ & $12.4 \pm 0.4^{\mathrm{b}}$ & $12.9 \pm 0.6^{b}$ & $13.2 \pm 0.5^{b}$ & $11.1 \pm 0.7^{\mathrm{b}}$ & $12.4 \pm 0.8^{b}$ \\
\hline $18: 1 n-7$ & $1.1 \pm 0.1^{\mathrm{a}}$ & $1.9 \pm 0.3^{\mathrm{a}}$ & $1.5 \pm 0.1^{\mathrm{a}}$ & $1.4 \pm 0.4^{\mathrm{a}}$ & $1.3 \pm 0.4^{\mathrm{a}}$ & $1.8 \pm 0.3^{a}$ & $1.7 \pm 0.3^{\mathrm{a}}$ \\
\hline $20: 1 n-9$ & $3.6 \pm 0.2^{\mathrm{a}}$ & $4.1 \pm 0.4^{\mathrm{a}}$ & $3.2 \pm 0.3^{\mathrm{a}}$ & $3.0 \pm 0.2^{\mathrm{a}}$ & $3.4 \pm 0.2^{\mathrm{a}}$ & $3.4 \pm 0.2^{a}$ & $3.3 \pm 0.3^{\mathrm{a}}$ \\
\hline $22: 1 n-9$ & $0.0 \pm 0.0^{\mathrm{a}}$ & $0.0 \pm 0.0^{\mathrm{a}}$ & $0.0 \pm 0.0^{\mathrm{a}}$ & $0.0 \pm 0.0^{\mathrm{a}}$ & $0.0 \pm 0.0^{a}$ & $0.0 \pm 0.0^{a}$ & $0.0 \pm 0.0^{a}$ \\
\hline Total $\mathrm{N}$ & $21.4 \pm 0.7^{\mathrm{a}}$ & $21.6 \pm 0.9^{\mathrm{a}}$ & $20.2 \pm 0.7^{\mathrm{a}}$ & $18.5 \pm 0.7^{\mathrm{a}}$ & $19.4 \pm 0.7^{\mathrm{a}}$ & $18.4 \pm 1.0^{\mathrm{a}}$ & $19.9 \pm 1.0^{\mathrm{a}}$ \\
\hline $18: 2 n-6$ & $6.8 \pm 0.3^{\mathrm{a}}$ & $5.5 \pm 0.2^{\mathrm{a}}$ & $5.3 \pm 0.2^{a}$ & $4.9 \pm 0.3^{\mathrm{a}}$ & $4.6 \pm 0.1^{a}$ & $4.1 \pm 0.3^{\mathrm{a}}$ & $3.9 \pm 0.5^{a}$ \\
\hline $20: 4$ & $3.4 \pm 0.2^{\mathrm{d}}$ & $3.5 \pm 0.2^{\mathrm{d}}$ & $5.1 \pm 0.4^{\mathrm{cd}}$ & $6.5 \pm 0.4^{b c}$ & $7.6 \pm 0.4^{b}$ & $8.5 \pm 0.6^{a b}$ & $10.3 \pm 0.8^{a}$ \\
\hline-6 & $0.2 \pm 0.0^{\mathrm{d}}$ & $0.3 \pm 0.0^{\mathrm{d}}$ & $0.5 \pm 0.0^{c}$ & $0.9 \pm 0.1^{b}$ & $0.8 \pm 0.0^{\mathrm{b}}$ & $1.3 \pm 0.1^{\mathrm{a}}$ & $1.4 \pm 0.1^{\mathrm{a}}$ \\
\hline $22: 5 n-6$ & $4 \pm 0.0^{c}$ & $0.5 \pm 0.0^{b c}$ & $0.5 \pm 0.1^{b c}$ & $0.7 \pm 0.1 \mathrm{bc}$ & $0.6 \pm 0.1^{a b}$ & $0.7 \pm 0.1^{a b}$ & $0.9 \pm 0.0^{\mathrm{a}}$ \\
\hline Tot & $11.3 \pm 0.3^{c}$ & $10.3 \pm 0.3^{c}$ & $11.7 \pm 0.3^{c}$ & $14.5 \pm 0.6^{\mathrm{b}}$ & $14.0 \pm 0.5^{b}$ & $14.9 \pm 0.8^{b}$ & $17.3 \pm 0.7^{\mathrm{a}}$ \\
\hline $18: 3 n-3$ & $0.1 \pm 0.1^{a}$ & $0.1 \pm 0.1^{a}$ & $0.1 \pm 0.1^{a}$ & $0.1 \pm 0.0^{\mathrm{a}}$ & $0.1 \pm 0.0^{a}$ & $0.1 \pm 0.0^{a}$ & $0.2 \pm 0.1^{a}$ \\
\hline 18: & $0.6 \pm 0.0^{\mathrm{a}}$ & $0.5 \pm 0.1^{a}$ & $0.4 \pm 0.0^{\mathrm{a}}$ & $0.5 \pm 0.2^{a}$ & $0.5 \pm 0.1^{a}$ & $0.5 \pm 0.1^{a}$ & $0.4 \pm 0.1^{a}$ \\
\hline 2 & $0.2 \pm 0.1^{a}$ & $0.2 \pm 0.1^{a}$ & $0.2 \pm 0.1^{a}$ & $0.2 \pm 0.1^{a}$ & $0.2 \pm 0.1^{a}$ & $0.2 \pm 0.1^{a}$ & $0.1 \pm 0.1^{a}$ \\
\hline 2 & $7.5 \pm 0.3^{\mathrm{ab}}$ & $9.0 \pm 0.5^{\mathrm{a}}$ & $8.0 \pm 0.5^{\mathrm{ab}}$ & $7.4 \pm 0.4^{a b}$ & $7.2 \pm 0.1^{\mathrm{b}}$ & $6.7 \pm 0.2^{b}$ & $6.6 \pm 0.2^{b}$ \\
\hline 2 & $6.0 \pm 0.3^{a}$ & $6.0 \pm 0.4^{\mathrm{a}}$ & $5.4 \pm 0.3^{a}$ & $5.9 \pm 0.4^{\mathrm{a}}$ & $4.5 \pm 0.3^{\mathrm{a}}$ & $5.0 \pm 0.3^{\mathrm{a}}$ & $4.6 \pm 0.4^{\mathrm{a}}$ \\
\hline $22: 6 n$ & $19.4 \pm 1.1^{\mathrm{a}}$ & $23.2 \pm 1.0^{\mathrm{a}}$ & $24.7 \pm 1.3^{a}$ & $23.7 \pm 0.7^{\mathrm{a}}$ & $23.4 \pm 1.3^{\mathrm{a}}$ & $19.7 \pm 0.9^{\mathrm{a}}$ & $21.2 \pm 1.4^{a}$ \\
\hline Total & $34.9 \pm 1.3^{\mathrm{a}}$ & $39.1 \pm 1.2^{\mathrm{a}}$ & $38.1 \pm 1.1^{\mathrm{a}}$ & $37.7 \pm 0.8^{\mathrm{a}}$ & $36.6 \pm 1.7^{\mathrm{a}}$ & $32.5 \pm 1.0^{b}$ & $33.8 \pm 1.6^{\mathrm{a}}$ \\
\hline Total PUFA & $46.2 \pm 1.4^{\mathrm{a}}$ & $49.4 \pm 1.4^{\mathrm{a}}$ & $49.8 \pm 1.2^{\mathrm{a}}$ & $52.2 \pm 1.3^{a}$ & $50.6 \pm 1.9^{a}$ & $47.4 \pm 1.5^{\mathrm{a}}$ & $51.1 \pm 2.1^{a}$ \\
\hline EPA/ARA & $2.4 \pm 0.2^{\mathrm{ab}}$ & $2.6 \pm 0.3^{a}$ & $1.7 \pm 0.1^{b}$ & $1.1 \pm 0.1^{\mathrm{c}}$ & $0.9 \pm 0.0^{c}$ & $0.8 \pm 0.1^{\mathrm{c}}$ & $0.6 \pm 0.1^{c}$ \\
\hline EPA/DHA & $0.4 \pm 0.0^{\mathrm{a}}$ & $0.4 \pm 0.0^{a}$ & $0.3 \pm 0.0^{\mathrm{a}}$ & $0.3 \pm 0.0^{\mathrm{a}}$ & $0.3 \pm 0.0^{a}$ & $0.4 \pm 0.0^{a}$ & $0.4 \pm 0.0^{\mathrm{a}}$ \\
\hline D & $6.0 \pm 0.4^{a b}$ & $7.1 \pm 0.3^{\mathrm{a}}$ & $5.0 \pm 0.4^{b c}$ & $3.2 \pm 0.3^{\mathrm{cd}}$ & $3.0 \pm 0.1^{\mathrm{d}}$ & $2.4 \pm 0.1^{\mathrm{d}}$ & $2.1 \pm 0.1^{\mathrm{d}}$ \\
\hline$n-3 / n-6$ & $1 \pm 0.1^{b}$ & $3.8 \pm 0.1^{a}$ & $3.3 \pm 0.1^{b}$ & $2.6 \pm 0.1^{c}$ & $2.5 \pm 0.1^{\mathrm{d}}$ & $2.2 \pm 0.1^{\mathrm{d}}$ & $2.0 \pm 0.1^{\mathrm{d}}$ \\
\hline
\end{tabular}

Abbreviation as in table 4. 